\title{
18. WHOLE-ROCK GEOCHEMISTRY AND Sr-, Nd-, AND Pb-ISOTOPIC CHARACTERISTICS OF UNDEFORMED, DEFORMED, AND RECRYSTALLIZED GABBROS FROM SITES 921, 922, AND 923 IN THE MARK AREA ${ }^{1}$
}

\author{
Jane Barling, ${ }^{2}$ Jan Hertogen, ${ }^{3}$ and Dominique Weis ${ }^{2}$
}

\begin{abstract}
Gabbros and diabases from Layer 3 of the oceanic lithosphere were recovered from the western wall of the Mid-Atlantic Rift Valley near the Kane Fracture Zone $\left(23.5^{\circ} \mathrm{N}, 45^{\circ} \mathrm{W}\right)$ during Ocean Drilling Program Leg 153 . Thirty-five gabbroic samples from Sites 921 to 923 and three diabases from Sites 920 and 921 have been analyzed for major and trace elements. The gabbroic samples were chosen to be representative of range of composition and variation in degree of deformation. Sr-, Nd-, and $\mathrm{Pb}$-isotope ratios were measured for 19 of the gabbros and a single diabase.

Trace-element variations, in particular, reflect the nature of the samples, which varies from troctolite to gabbro (sensu stricto) to Fe-Ti-oxide-rich gabbro. Interpretation of the rare-earth element (REE) and Sc characteristics of the gabbros leads to contrasting models for the origin of gabbros from Sites 921 and 923 as compared to those from Site 922 . Site 921 and 923 troctolitic rocks and gabbros (sensu stricto) can be modeled as comprising a fairly primitive cumulate fraction plus trapped parental intercumulus liquid. Second-order trace-element variations are indicative of fractionation attending adcumulus growth and compaction. The Site 922 troctolitic gabbros (sensu lato) are remarkable because of the high REE abundances and high REE/Sc ratios, characteristics normally associated with evolved compositions. The REE geochemistry of these troctolites cannot be accounted for by mixing between primitive troctolites and diabase liquid as for gabbros from Sites 921 and 923 . Instead, these troctolites are modeled as mixtures between barren troctolites and a strongly enriched liquid. Such a liquid is likely to have accompanied the formation of the $\mathrm{Fe}-\mathrm{Ti}$ oxide gabbros with which these troctolites are associated.

$\mathrm{Sr}-, \mathrm{Nd}-$, and $\mathrm{Pb}$-isotope ratios for undeformed and deformed and recrystallized gabbros from Sites 921 and 923 have a very restricted range of values: ${ }^{87} \mathrm{Sr} /{ }^{86} \mathrm{Sr}=0.70234-0.70239 ;{ }^{143} \mathrm{Nd} /{ }^{144} \mathrm{Nd}=0.51324-0.51319 ;{ }^{206} \mathrm{~Pb} /{ }^{204} \mathrm{~Pb}=18.02-18.07 ;{ }^{207} \mathrm{~Pb} /$ ${ }^{204} \mathrm{~Pb}=15.42-15.47$; and ${ }^{208} \mathrm{~Pb} /{ }^{204} \mathrm{~Pb}=37.37-37.54$. Gabbros from Site 922 have a similar range of $\mathrm{Nd}$ - and $\mathrm{Pb}$-isotope compositions to Site 921 and 923 gabbros, but at a given ${ }^{206} \mathrm{~Pb} /{ }^{204} \mathrm{~Pb}$ value they have slightly lower ${ }^{207} \mathrm{~Pb} / 204 \mathrm{~Pb}$ and ${ }^{208} \mathrm{~Pb} /{ }^{204} \mathrm{~Pb}$ ratios. This may indicate the involvement of a component with isotopically distinct $\mathrm{Pb}$ in the generation of these gabbros. Site 922 gabbros also have more variable Sr-isotope compositions $\left.{ }^{(87} \mathrm{Sr} /{ }^{86} \mathrm{Sr}=0.70235-0.70251\right)$ than Site 921 and 923 gabbros. However, this is probably caused by incomplete removal of secondary radiogenic $\mathrm{Sr}$ introduced during alteration. The Site 921 diabase has more radiogenic $\mathrm{Sr}-\left({ }^{87} \mathrm{Sr} /{ }^{86} \mathrm{Sr}=0.70243\right)$ and $\mathrm{Pb}-\left(\mathrm{e} . \mathrm{g} .,{ }^{206} \mathrm{~Pb} /{ }^{004} \mathrm{~Pb}=18.12\right)$ isotope ratios than Site 921 and 923 gabbros, but its ${ }^{143} \mathrm{Nd} / /^{144} \mathrm{Nd}(0.513221)$ is within the range of values for all gabbros. The $\mathrm{Sr}-, \mathrm{Nd}-$, and $\mathrm{Pb}$-isotope ratios of both the gabbros and the diabase are typical of mid-ocean ridge basalts (MORB) and lie toward the depleted extreme of values for Atlantic MORB.
\end{abstract}

\section{INTRODUCTION}

Gabbroic cumulates were recovered at Sites 921, 922, and 923 on the western wall of the Mid-Atlantic Rift Valley near the Kane Fracture Zone (MARK area: $23.5^{\circ} \mathrm{N}, 045^{\circ} \mathrm{W}$ ). The gabbros (sensu lato) exposed at these sites are considered to come from Layer 3 of the oceanic lithosphere and to have been exposed as a result of mechanical extension during a period of very limited magmatic construction (Cannat, Karson, Miller, et al., 1995). Oceanic Layer 3 has a predominantly cumulate nature. However, it is not yet clearly understood how much intercumulus liquid has been retained on average, and many unanswered questions remain about the fate of highly enriched residual liquids resulting from the crystallization of gabbroic cumulates. Do they mingle with the basaltic liquids that build up Layer 2 and, in so-doing, cause the second-order variations in trace-element ratios that are observed in the extrusive series? Or are the residual liquids largely retained in highly enriched pods within the cumulus pile? A case in point are the strongly enriched $\mathrm{Fe}$-Ti oxide gabbros drilled

'Karson, J.A., Cannat, M., Miller, D.J., and Elthon, D. (Eds.), 1997. Proc. ODP, Sci. Results, 153: College Station, TX (Ocean Drilling Program).

2Département des Sciences de la Terre et de l'Environnement, C.P. 160/02, Université Libre de Bruxelles, Av. F.D. Roosevelt 50, B-1050 Bruxelles, Belgium. Presen address: Geologisk Institut, Københavns Universitet, Øster Voldgade 10, DK-1350 København K, Denmark. Jane.Barling@pop.geol.ku.dk

${ }^{3}$ Fysico-chemische geologie, University of Leuven, Celestijnenlaan 200C, B-3001 Leuven, Belgium. in Hole 735B (Ocean Drilling Program [ODP] Leg 118; Robinson, Von Herzen, et al., 1989). A proper understanding of the role of residual liquids is thus essential for geochemical balances of the complete oceanic crust. Furthermore, trace-element and isotopic studies can also shed light on the extent to which the gabbroic pile has been altered by late-stage, fluid alteration, a process that could be promoted locally by shearing of the cumulate pile as a result of tectonic activity associated with the extensional environment.

It is with the aim of addressing these problems that we have undertaken a geochemical and isotopic study of the compositional and deformational spectrum of gabbros from Sites 921, 922, and 923 .

\section{SAMPLE SELECTION AND PREPARATION}

Our sampling strategy was simple. For Sites 921, 922, and 923, we tried to sample each of the shipboard-defined units and took additional samples to cover the greatest possible range of lithologies and states of deformation. Deformed gabbros were sampled to determine the effect, if any, of deformation and recrystallization on the primary characteristics of the gabbros. Therefore, they were, as far as possible, paired with similar undeformed or less-deformed lithologies sampled in close proximity to eliminate as many variables as possible when comparing the deformed and undeformed compositions. Five of these sample pairs were selected for analysis: Samples 153-921B3R-1, 20-27 cm, and 3R-1, 140-144 cm; Samples 153-921E-2R-2, 
44-50 cm, and 3R-1, 30-36 cm; Samples 153-923A-2R-1, 22$24 \mathrm{~cm}$, and 5R-1, 39-45 cm; coarse-grained and fine-grained facies from both Sample 153-923A-2R-2, 23-30 cm, and Sample 153$923 \mathrm{~A}-11 \mathrm{R}-1,48-55 \mathrm{~cm}$. The last two samples contain contacts between different deformational facies that were separated for analysis. In Sample 153-923A-2R-2, 23-30 cm, the contact is between finegrained mylonitic gabbronorite and almost undeformed, coarsegrained protolith. In Sample 153-923A-11R-1, 48-55 cm, a gabbro, the contact is between a coarse-grained porphyroclastic facies and a fine-grained mylonitic facies (G. Ceuleneer, pers. comm., 1995).

In addition, the data set includes diabases from Sites 920 and 921 , and the shipboard gabbro standard (GABY). Gabbros from Site 924 were not sampled because they were generally highly altered and no shipboard thin sections or geochemical data were available as a guide to sampling.

To remove all traces of organic and inorganic contaminants before crushing, samples were scrubbed and ultrasonically cleaned in acetone and ethanol. Remaining saw marks, ODP labels, and wax sampling marks were ground off, and the samples were rinsed in water. The cleaned samples were wrapped in plastic and broken into centimeter-scale chips using a steel chisel. These were crushed to millimeter-scale using either an aluminum or a carbon steel pestle and mortar. An aliquot was ground to powder in an all-agate vibrating ball mill. Analyses of two samples (Sample 153-922A-2R-2, 106$111 \mathrm{~cm}$, and the GABY standard) were performed on powders prepared on the ship.

\section{ANALYTICAL METHODS}

For the determination of the major elements and $\mathrm{Ni}, 100 \mathrm{mg}$ of sample powder was fused with $0.5 \mathrm{~g}$ of Li-metaborate (Johnson Matthey, Spectroflux 100A) in a graphite crucible upon heating in a muffle furnace. The fusion cake was taken up in dilute nitric acid. The concentrations of the elements $\mathrm{Si}, \mathrm{Ti}, \mathrm{Al}, \mathrm{Fe}, \mathrm{Mn}, \mathrm{Mg}, \mathrm{Ca}, \mathrm{P}$, and $\mathrm{Ni}$ were measured using a direct-current plasma atomic emission (DCPAES) spectrometer (see Potts, 1987; and references therein). The alkali elements $\mathrm{Na}$ and $\mathrm{K}$ were analyzed by flame atomization absorption spectrometry (AAS). The weight loss on ignition (LOI) was measured on a separate $0.5 \mathrm{~g}$ sample aliquot heated for $1 \mathrm{hr}$ at $1000^{\circ} \mathrm{C}$ in a muffle furnace. LOI values set a lower limit to the total amount of volatile constituents because the heated samples also gain some weight by the oxidation of ferrous iron. Analytical precision of the major elements $\mathrm{Si}, \mathrm{Al}, \mathrm{Fe}, \mathrm{Mg}, \mathrm{Ca}$, and $\mathrm{Na}$ is estimated at $2 \%-3 \%$ (relative). $\mathrm{Fe}$ and $\mathrm{Na}$ also were measured together with the trace elements by instrumental neutron activation analysis (INAA). The two data sets generally agreed within the stated errors. Precision for the minor elements $\mathrm{Ti}, \mathrm{Mn}$, and $\mathrm{K}$ varies from $5 \%$ to $15 \%$ (relative), depending upon concentration. The $\mathrm{P}$ content of many analyzed samples was close to the detection limit of the analytical technique $(\sim 0.05$ wt $\%$ ). The precision of the results is rather poor: $50 \%$ to $100 \%$ (relative) for $\mathrm{P}_{2} \mathrm{O}_{5} \leq 0.1 \mathrm{wt} \%$.

The trace elements $\mathrm{Sc}, \mathrm{Cr}, \mathrm{Co}, \mathrm{REE}, \mathrm{Hf}, \mathrm{Ta}, \mathrm{Th}$, and $\mathrm{U}$ were determined in $800 \mathrm{mg}$ of sample powder by INAA. Samples were irradiated in the Thetis reactor of the University of Gent, Belgium, and the induced gamma-ray activities were measured at the University of Leuven. For details of the procedure, see Hertogen and Gijbels (1971). The samples were analyzed relative to a secondary in-house alkali basalt standard rock that has been repeatedly calibrated against international reference rocks. The analytical precision of the trace-element data is variable: generally better than $5 \%$ (relative) for the elements $\mathrm{Sc}, \mathrm{Cr}, \mathrm{Co}, \mathrm{Sm}$, and Eu; between $5 \%$ and $10 \%$ (relative) for $\mathrm{La}, \mathrm{Tb}, \mathrm{Yb}$, and $\mathrm{Hf}$; precision of the elements $\mathrm{Ce}, \mathrm{Nd}, \mathrm{Lu}$, and $\mathrm{Ta}$ varies from $5 \%$ to $25 \%$, depending upon concentration. No data are reported for the elements $\mathrm{Ba}$, Th, and $\mathrm{U}$ because the abundances are below or very close to the detection limit of the INAA technique in all the samples ( $20 \mathrm{ppm}$ for $\mathrm{Ba}, 0.07 \mathrm{ppm}$ for Th, and $0.1 \mathrm{ppm}$ for $\mathrm{U}$ ).
For 19 gabbros, a single diabase, and the GABY standard, an aliquot of the powder was analyzed for $\mathrm{Sr}-, \mathrm{Nd}-$, and $\mathrm{Pb}$-isotope ratios at the Université Libre de Bruxelles (ULB) and the Dansk Center for Isotopgeologi at Københavns Universitet (KU). To eliminate all traces of secondary $\mathrm{Sr}, \mathrm{Nd}$, and $\mathrm{Pb}$, such as might be introduced by circulating seawater or low-temperature hydrothermal fluids, all samples were ultrasonically leached repeatedly (between 7 and 12 times) in cold, 6- $\mathrm{M} \mathrm{HCl}$ until a final, almost colorless, leachate resulted. For several samples, a second aliquot was leached and dissolved at KU. The leaching technique used at $\mathrm{KU}$ was identical to the technique used at ULB, except that the ultrasonic leach was repeated 19 to 22 times. The GABY standard was also treated with a 6-hr leach in hot, $6-\mathrm{M} \mathrm{HCl}$ to compare this method of leaching with our ultrasonic leaching method. The weight of the original aliquots of sample varied from $100 \mathrm{mg}$ to $450 \mathrm{mg}$; the larger weights were chosen for samples with low $\mathrm{Sm}, \mathrm{Nd}$, and $\mathrm{Pb}$ contents, and to compensate for greater expected losses upon leaching for the more pervasively altered samples.

After leaching, the residue was rinsed in MilliQ water, dried, and weighed before being dissolved in a 6:1 mixture of $\mathrm{HF}$ and $\mathrm{HNO}_{3}$ in a closed polyfluorethylene (Savillex) beaker. The dissolved samples were then passed through anion exchange columns from which $\mathrm{Pb}$ was collected. $\mathrm{Sr}$ and $\mathrm{REE}$, which are contained in the eluted fraction from the anion exchange step, were then separated on cation-exchange columns, and finally, Nd was separated from the other REE on columns containing HDEHP coated teflon. Details of this procedure can be found in Weis and Deutsch (1984). Isotope ratios were measured using VG sector 54 mass spectrometers. Sr- and Nd-isotope ratios were measured using dynamic multicollection at both $\mathrm{ULB}$ and $\mathrm{KU}$. All Pb-isotope ratios were measured statically at ULB.

${ }^{87} \mathrm{Sr} /{ }^{86} \mathrm{Sr}$ ratios are normalized to ${ }^{86} \mathrm{Sr} /{ }^{88} \mathrm{Sr}=0.1194$. During the period of measurement, ${ }^{87} \mathrm{Sr} /{ }^{86} \mathrm{Sr}$ for the National Institute of Standards and Technology (NIST) Sr standard NIST 987 was 0.710268 (standard deviation $[\mathrm{SD}]=0.000008 ; \mathrm{n}=6$ ) at ULB, and 0.710272 $(\mathrm{SD}=0.000002 ; \mathrm{n}=3)$ at $\mathrm{KU}$. The $\mathrm{Sr}$-isotope data from the two laboratories are thus directly comparable.

${ }^{143} \mathrm{Nd} /{ }^{144} \mathrm{Nd}$ ratios are normalized to ${ }^{146} \mathrm{Nd} /{ }^{144} \mathrm{Nd}=0.7219$. At ULB, the Merck Nd standard was measured. This gave ${ }^{143} \mathrm{Nd} /{ }^{144} \mathrm{Nd}=$ $0.511737(\mathrm{SD}=0.000013 ; \mathrm{n}=3)$ and $0.511721(\mathrm{SD}=0.000016 ; \mathrm{n}=$ 5) during two different periods of measurement. The ULB data are reported relative to a Merck $\mathrm{Nd}$ standard ${ }^{143} \mathrm{Nd} /{ }^{144} \mathrm{Nd}$ value of 0.511737 . At KU, the Johnson Matthey Nd standard was measured. This gave ${ }^{143} \mathrm{Nd} /{ }^{144} \mathrm{Nd}=0.511130(\mathrm{SD}=0.000008 ; \mathrm{n}=5)$. Reported values for this standard range from ${ }^{143} \mathrm{Nd} /{ }^{144} \mathrm{Nd}=0.511109$ to 0.511129 (Mearns, 1988; Mearns et al., 1989; Vance and O'Nions, 1990).

$\mathrm{Pb}$-isotope ratios were corrected for fractionation relative to the NIST $981 \mathrm{~Pb}$ standard by $0.06 \%-0.14 \% \mathrm{amu}^{-1}$, depending on the filament temperature during the measurement. Reproducibility of NIST 981 under normal running conditions $\left(1150^{\circ} \mathrm{C}-1225^{\circ} \mathrm{C}\right)$ was better than $0.038 \% \mathrm{amu}^{-1}$ (2 SD). However, some samples had to be measured at $1250^{\circ} \mathrm{C}$, and, at this temperature, reproducibility was $0.074 \%$ $\mathrm{amu}^{-1}$ (2 SD).

\section{RESULTS Major-Element and Trace-Element Composition}

The results of the chemical analyses are summarized in Table 1. When comparing the major-element compositions listed in Table 1 with the shipboard data reported in Cannat, Karson, Miller, et al. (1995), one should keep in mind that data in Table 1 are measured on the ground powders as such, whereas shipboard data refer to the composition of ignited devolatilized powders. The effect of this is most noticeable for the high-abundance elements, such as $\mathrm{Si}$ and $\mathrm{Al}$. Figure 1 shows the variation of the $\mathrm{Ni}$ content with $\mathrm{Mg}$ number $(\mathrm{Mg} \#)$. The figure mainly serves to show that the subset of samples analyzed in the present study covers virtually the whole range of variation exhib- 
Table 1. Chemical composition of gabbroic rocks from Sites 920 to 923.

\begin{tabular}{|c|c|c|c|c|c|c|c|c|c|c|c|c|}
\hline Hole: & $920 \mathrm{D}$ & $921 \mathrm{~B}$ & $921 \mathrm{~B}$ & $921 \mathrm{~B}$ & $921 \mathrm{~B}$ & $921 \mathrm{~B}$ & $921 \mathrm{~B}$ & $921 \mathrm{~B}$ & $921 \mathrm{~B}$ & $921 \mathrm{C}$ & $921 \mathrm{E}$ & $921 \mathrm{E}$ \\
\hline $\begin{array}{l}\text { Core, } \\
\text { section: }\end{array}$ & $9 \mathrm{R}-2$ & $1 \mathrm{~W}-1$ & $1 \mathrm{~W}-2$ & $3 \mathrm{R}-1$ & $3 R-1$ & $3 R-2$ & $4 \mathrm{R}-1$ & $4 \mathrm{R}-2$ & $4 R-3$ & $2 \mathrm{R}-1$ & $2 \mathrm{R}-2$ & $3 R-1$ \\
\hline Interval: & $33-38$ & $78-83$ & $10-14$ & $20-27$ & $140-144$ & $34-38$ & $44-50$ & $30-36$ & $6-12$ & $16-22$ & $44-50$ & $30-36$ \\
\hline Piece no.: & 2 & 10 & 2 & $2 / 3$ & 13 & 4 & $6 \mathrm{~A}$ & 1 & 1 & 3 & 3 & $4 B$ \\
\hline Type: & DIA & GAB & DIA & OLG & OLG & GAB & OLG & OLG/TRO & OLG & DIA & GAB & $\mathrm{GAB}$ \\
\hline \multicolumn{13}{|c|}{ Major elements (wt\%) } \\
\hline $\mathrm{SiO}_{2}$ & 47.41 & 51.79 & 47.65 & 51.01 & 51.60 & 51.00 & 47.37 & 47.34 & 45.90 & 47.94 & 52.71 & 52.82 \\
\hline $\mathrm{TiO}_{2}$ & 0.84 & 0.40 & 1.27 & 0.38 & 0.38 & 0.53 & 0.28 & 0.20 & 0.16 & 1.03 & 0.50 & 0.72 \\
\hline $\mathrm{Al}_{2} \mathrm{O}_{3}$ & 15.90 & 14.71 & 16.19 & 15.40 & 16.21 & 16.30 & 16.92 & 19.86 & 17.95 & 15.38 & 13.67 & 14.63 \\
\hline $\mathrm{Fe}_{2} \mathrm{O}_{3}$ & 8.01 & 6.09 & 9.48 & 5.92 & 6.13 & 6.22 & 5.86 & 6.60 & 6.70 & 9.34 & 8.24 & 9.44 \\
\hline $\mathrm{MnO}$ & 0.22 & 0.14 & 0.18 & 0.12 & 0.13 & 0.13 & 0.10 & 0.10 & 0.11 & 0.16 & 0.16 & 0.17 \\
\hline $\mathrm{MgO}$ & 11.59 & 9.62 & 8.81 & 10.61 & 9.08 & 9.31 & 12.36 & 12.07 & 13.53 & 9.56 & 9.91 & 8.40 \\
\hline $\mathrm{CaO}$ & 8.82 & 12.68 & 11.33 & 13.97 & 13.29 & 13.41 & 13.73 & 10.53 & 11.72 & 11.59 & 12.65 & 10.99 \\
\hline $\mathrm{Na}_{2} \mathrm{O}$ & 2.86 & 3.03 & 2.82 & 2.42 & 2.90 & 2.70 & 2.10 & 2.33 & 2.15 & 2.52 & 2.58 & 2.97 \\
\hline $\mathrm{K}_{2} \mathrm{O}$ & 0.07 & 0.05 & 0.04 & 0.04 & 0.04 & 0.03 & 0.04 & 0.05 & 0.04 & 0.04 & 0.05 & 0.08 \\
\hline $\mathrm{P}_{2} \mathrm{O}_{5}$ & 0.07 & 0.06 & 0.14 & 0.06 & 0.07 & 0.08 & 0.06 & 0.08 & 0.05 & 0.10 & 0.08 & 0.07 \\
\hline LOI & 4.44 & 1.79 & 2.39 & 0.32 & 0.39 & 0.44 & 0.92 & 1.04 & 1.23 & 2.60 & 0.23 & 0.39 \\
\hline TOT & 100.23 & 100.36 & 100.30 & 100.25 & 100.22 & 100.15 & 99.74 & 100.20 & 99.54 & 100.26 & 100.78 & 100.68 \\
\hline Mg\# & 0.77 & 0.78 & 0.68 & 0.81 & 0.77 & 0.78 & 0.83 & 0.81 & 0.82 & 0.70 & 0.74 & 0.67 \\
\hline \multicolumn{13}{|c|}{ Trace elements (ppm) } \\
\hline $\mathrm{Sc}$ & 27.7 & 41.6 & 35.3 & 41.2 & 40.9 & 39.6 & 28 & 5.4 & 12.2 & 31.7 & 41.4 & 33.7 \\
\hline $\mathrm{Cr}$ & 399 & 127 & 307 & 570 & 73 & 193 & 1284 & 52 & 501 & 310 & 194 & 203 \\
\hline Co & 45.7 & 34.2 & 39.6 & 37.6 & 35.8 & 35.6 & 41.1 & 52.5 & 52.6 & 40.6 & 48.0 & 56.3 \\
\hline $\mathrm{Ni}$ & 211 & 100 & 131 & 139 & 95 & 106 & 235 & 355 & 304 & 160 & 146 & 114 \\
\hline $\mathrm{La}$ & 2.0 & 0.47 & 2.5 & 0.49 & 0.37 & 0.52 & 0.44 & 0.49 & 0.36 & 2.3 & 0.74 & 1.7 \\
\hline $\mathrm{Ce}$ & 6.6 & 1.9 & 8.5 & 1.8 & 1.5 & 2.2 & 1.6 & 1.3 & 0.98 & 7.7 & 2.7 & 6.0 \\
\hline $\mathrm{Nd}$ & 5.5 & 1.9 & 9.0 & 2.1 & 1.7 & 2.8 & 2.0 & 1.0 & 1.0 & 7.4 & 3.1 & 5.2 \\
\hline Sm & 1.95 & 0.98 & 3.0 & 0.96 & 0.87 & 1.1 & 0.6 & 0.31 & 0.30 & 2.56 & 1.3 & 1.78 \\
\hline Eu & 0.86 & 0.55 & 1.21 & 0.53 & 0.58 & 0.63 & 0.43 & 0.34 & 0.33 & 1.06 & 0.74 & 0.91 \\
\hline $\mathrm{Tb}$ & 0.48 & 0.29 & 0.73 & 0.28 & 0.27 & 0.31 & 0.16 & 0.065 & 0.067 & 0.62 & 0.36 & 0.46 \\
\hline $\mathrm{Yb}$ & 1.98 & 1.09 & 2.62 & 1.03 & 1.02 & 1.21 & 0.64 & 0.23 & 0.29 & 2.33 & 1.36 & 2.02 \\
\hline $\mathrm{Lu}$ & 0.29 & 0.18 & 0.38 & 0.17 & 0.15 & 0.19 & 0.10 & 0.043 & 0.053 & 0.34 & 0.21 & 0.30 \\
\hline $\mathrm{Hf}$ & 1.37 & 0.41 & 2.1 & 0.42 & 0.33 & 0.56 & 0.34 & 0.15 & 0.14 & 1.81 & 0.67 & 0.89 \\
\hline $\mathrm{Ta}$ & 0.061 & $<0.005$ & 0.092 & $<0.005$ & $<0.005$ & 0.018 & 0.010 & 0.016 & 0.008 & 0.075 & 0.010 & 0.050 \\
\hline
\end{tabular}

Notes: Coarse and fine $=$ coarse- and fine-grained lithologies separated from the same piece; $\mathrm{Fe}_{2} \mathrm{O}_{3}=$ total iron expressed as $\mathrm{Fe} 2 \mathrm{O}_{3} ; \mathrm{LOI}=$ loss on ignition; $\mathrm{TOT}$ = total; $\mathrm{Mg \#} \mathrm{=} \mathrm{calculated} \mathrm{molar} \mathrm{ratio} \mathrm{Mg} /(\mathrm{Mg}+0.85 \times \mathrm{FeTot}) ; \mathrm{TRO}=$ troctolite; OLG = olivine gabbro; $\mathrm{GAB}=$ olivine-poor gabbro; $\mathrm{GNO}=$ gabbronorite; $\mathrm{OXG}=$ oxide-rich gabbro; $\mathrm{DIA}=$ diabase; cont $=$ Ta contamination from tungsten carbide mill in samples prepared on the ship; Interlab. $=$ interlaboratory .

Table 1 (continued).

\begin{tabular}{|c|c|c|c|c|c|c|c|c|c|c|c|c|}
\hline Hole: & $921 \mathrm{E}$ & $921 \mathrm{E}$ & $921 \mathrm{E}$ & $922 \mathrm{~A}$ & $922 \mathrm{~A}$ & $922 \mathrm{~A}$ & $922 \mathrm{~A}$ & $922 \mathrm{~B}$ & $922 \mathrm{~B}$ & $922 \mathrm{~B}$ & $922 \mathrm{~B}$ & $923 \mathrm{~A}$ \\
\hline $\begin{array}{l}\text { Core, } \\
\text { section: }\end{array}$ & $3 R-1$ & $5 \mathrm{R}-2$ & $8 R-2$ & $2 \mathrm{R}-1$ & 2R-2 & $2 R-3$ & $3 R-1$ & 1W-1 & IW-1 & 2R-2 & $3 R-1$ & 2R-I \\
\hline Interval: & $129-134$ & $88-94$ & $32-40$ & $131-136$ & $106-111$ & $37-44$ & $94-100$ & $86-91$ & $109-115$ & $77-80$ & $37-43$ & $22-24$ \\
\hline Piece no.: & 15 & 5 & 4 & 8 & 2 & 1B & $4 B$ & 6 & 8 & 7 & 3 & 3 \\
\hline Type: & GAB & OLG & GAB & TRO & OXG & OLG & OXG & OLG & OLG & GNO & OLG & GAB \\
\hline \multicolumn{13}{|c|}{ Major elements (wt\%) } \\
\hline $\mathrm{SiO}_{2}$ & 53.62 & 49.95 & 54.71 & 46.23 & 46.24 & 48.21 & 47.45 & 47.91 & 42.61 & 45.51 & 46.16 & 51.51 \\
\hline $\mathrm{TiO}_{2}$ & 0.41 & 0.28 & 0.68 & 0.17 & 2.06 & 0.24 & 2.65 & 0.34 & 0.87 & 2.41 & 0.54 & 0.31 \\
\hline $\mathrm{Al}_{2} \mathrm{O}_{3}$ & 15.02 & 17.02 & 15.53 & 20.00 & 16.73 & 18.37 & 11.19 & 19.36 & 22.35 & 15.11 & 20.51 & 15.53 \\
\hline $\mathrm{Fe}_{2} \mathrm{O}_{3}$ & 5.75 & 5.11 & 6.77 & 5.57 & 13.42 & 6.09 & 15.92 & 4.99 & 8.07 & 12.96 & 5.76 & 7.40 \\
\hline $\mathrm{MnO}^{3}$ & 0.11 & 0.10 & 0.15 & 0.09 & 0.21 & 0.10 & 0.34 & 0.10 & 0.14 & 0.25 & 0.09 & 0.15 \\
\hline $\mathrm{MgO}$ & 8.86 & 10.32 & 6.83 & 13.38 & 7.27 & 12.93 & 9.22 & 10.74 & 11.24 & 6.86 & 9.80 & 9.79 \\
\hline $\mathrm{CaO}$ & 13.09 & 14.62 & 11.95 & 10.84 & 9.68 & 10.44 & 9.34 & 12.31 & 10.77 & 11.32 & 11.89 & 12.30 \\
\hline $\mathrm{Na}_{2} \mathrm{O}$ & 2.74 & 2.25 & 3.36 & 1.87 & 2.92 & 1.86 & 2.44 & 2.13 & 2.17 & 3.22 & 1.97 & 2.71 \\
\hline $\mathrm{K}_{2} \mathrm{O}$ & 0.08 & 0.04 & 0.07 & 0.07 & 0.07 & 0.05 & 0.07 & 0.08 & 0.07 & 0.07 & 0.05 & 0.04 \\
\hline $\mathrm{P}_{2} \mathrm{O}_{5}$ & 0.06 & 0.11 & 0.09 & 0.04 & 1.23 & 0.06 & 1.18 & 0.09 & 0.81 & 1.47 & 0.09 & 0.05 \\
\hline LOI & 0.65 & 0.47 & 0.33 & 1.02 & 0.44 & 1.29 & 0.66 & 1.23 & 0.85 & 1.06 & 2.30 & 0.60 \\
\hline TOT & 100.39 & 100.27 & 100.47 & 99.28 & 100.27 & 99.64 & 100.46 & 99.28 & 99.95 & 100.24 & 99.16 & 100.39 \\
\hline $\mathrm{Mg} \#$ & 0.78 & 0.82 & 0.70 & 0.85 & 0.56 & 0.83 & 0.57 & 0.83 & 0.76 & 0.55 & 0.80 & 0.75 \\
\hline \multicolumn{13}{|c|}{ Trace elements (ppm) } \\
\hline $\mathrm{Sc}$ & 35.3 & 35.1 & 43.4 & 5.9 & 10.5 & 6.8 & 30.1 & 12.7 & 11.2 & 23.9 & 7.6 & 35.7 \\
\hline $\mathrm{Cr}$ & 394 & 641 & 66 & 118 & 34 & 136 & 176 & 374 & 428 & 48 & 143 & 325 \\
\hline Co & 34.9 & 35.4 & 30.0 & 49.6 & 50.9 & 50.0 & 51.6 & 38.3 & 45.4 & 37.4 & 40.4 & 48.7 \\
\hline $\mathrm{Ni}$ & 147 & 200 & 64 & 522 & 249 & 452 & 227 & 385 & 369 & 188 & 368 & 151 \\
\hline $\mathrm{La}$ & 1.5 & 0.34 & 1.7 & 1.06 & 11.2 & 1.5 & 11.9 & 1.9 & 2.6 & 18.3 & 1.76 & 0.44 \\
\hline $\mathrm{Ce}$ & 5.2 & 1.2 & 5.6 & 3.1 & 39.7 & 4.4 & 46 & 6.1 & 9.2 & 69 & 5.4 & 1.6 \\
\hline $\mathrm{Nd}$ & 4.4 & 1.5 & 6.2 & 2.4 & 41.1 & 3.7 & 48 & 4.8 & 8.4 & 71 & 4.5 & 1.9 \\
\hline $\mathrm{Sm}$ & 1.66 & 0.64 & 2.27 & 0.75 & 13.6 & 1.09 & 15.4 & 1.53 & 2.72 & 22.6 & 1.48 & 0.74 \\
\hline $\mathrm{Eu}$ & 0.72 & 0.43 & 1.16 & 0.43 & 3.66 & 0.54 & 3.95 & 0.68 & 1.04 & 5.4 & 0.59 & 0.51 \\
\hline $\mathrm{Tb}$ & 0.43 & 0.18 & 0.60 & 0.16 & 2.6 & 0.24 & 3.34 & 0.35 & 0.57 & 4.5 & 0.33 & 0.21 \\
\hline $\mathrm{Yb}$ & 1.75 & 0.71 & 2.49 & 0.65 & 5.7 & 1.05 & 8.9 & 1.51 & 1.80 & 11.7 & 1.21 & 0.84 \\
\hline $\mathrm{Lu}$ & 0.26 & 0.11 & 0.34 & 0.095 & 0.78 & 0.15 & 1.2 & 0.21 & 0.26 & 1.52 & 0.18 & 0.13 \\
\hline $\mathrm{Hf}$ & 0.76 & 0.25 & 1.02 & 0.49 & 1.3 & 0.72 & 2.4 & 0.96 & 1.18 & 7.5 & 1.12 & 0.35 \\
\hline $\mathrm{Ta}$ & 0.046 & $<0.005$ & 0.040 & 0.020 & cont & 0.040 & 0.59 & 0.048 & 0.077 & 0.56 & 0.074 & $<0.005$ \\
\hline
\end{tabular}


Table 1 (continued).

\begin{tabular}{|c|c|c|c|c|c|c|c|c|c|c|c|c|}
\hline Hole: & $923 \mathrm{~A}$ & $923 \mathrm{~A}$ & $923 \mathrm{~A}$ & $923 \mathrm{~A}$ & $923 \mathrm{~A}$ & $923 \mathrm{~A}$ & $923 \mathrm{~A}$ & $923 \mathrm{~A}$ & $923 \mathrm{~A}$ & $923 \mathrm{~A}$ & $923 \mathrm{~A}$ & GABY \\
\hline $\begin{array}{l}\text { Core, } \\
\text { section: }\end{array}$ & $2 \mathrm{R}-2$ & $2 \mathrm{R}-2$ & $5 \mathrm{R}-1$ & $8 \mathrm{R}-2$ & $9 \mathrm{R}-3$ & $11 \mathrm{R}-1$ & $11 \mathrm{R}-1$ & $11 \mathrm{R}-1$ & 13R-2 & $14 \mathrm{R}-1$ & $16 \mathrm{R}-1$ & Interlab. \\
\hline Interval: & $23-30$ & $23-30$ & $39-45$ & $54-61$ & $4-10$ & $48-55$ & $48-55$ & $63-69$ & $135-140$ & $3-8$ & $24-29$ & standard \\
\hline Piece no.: & 1 (coarse) & 1 (fine) & 2 & 6 & 1 & 7 (coarse) & 7 (fine) & 8 & 8 & 2 & 2 & \\
\hline Type: & GNO & GNO & GAB & TRO & OLG & GAB & GAB & GAB & OLG & TRO & OLG & OLG \\
\hline \multicolumn{13}{|c|}{ Major elements (wt\%) } \\
\hline $\mathrm{SiO}_{2}$ & 48.95 & 50.06 & 50.57 & 48.91 & 50.92 & 48.85 & 48.76 & 52.16 & 50.65 & 47.72 & 49.55 & 49.63 \\
\hline $\mathrm{TiO}_{2}$ & 0.83 & 0.65 & 0.41 & 0.17 & 0.36 & 0.33 & 0.30 & 0.27 & 0.48 & 0.19 & 0.29 & 0.29 \\
\hline $\mathrm{Al}_{2}^{2} \mathrm{O}_{3}$ & 17.53 & 18.36 & 15.47 & 21.83 & 16.64 & 19.61 & 17.98 & 15.61 & 14.91 & 18.59 & 18.78 & 16.56 \\
\hline $\mathrm{Fe}_{2} \mathrm{O}_{3}$ & 9.54 & 7.88 & 6.58 & 5.36 & 5.71 & 5.28 & 5.38 & 5.93 & 7.51 & 4.96 & 4.15 & 4.72 \\
\hline $\mathrm{MnO}$ & 0.20 & 0.19 & 0.13 & 0.09 & 0.12 & 0.11 & 0.12 & 0.13 & 0.15 & 0.10 & 0.08 & 0.09 \\
\hline $\mathrm{MgO}$ & 7.48 & 7.42 & 9.97 & 8.02 & 8.87 & 8.17 & 9.70 & 9.70 & 10.95 & 11.50 & 9.80 & 11.14 \\
\hline $\mathrm{CaO}$ & 11.20 & 11.32 & 14.01 & 11.25 & 14.47 & 13.62 & 14.19 & 13.48 & 12.80 & 12.43 & 14.87 & 14.53 \\
\hline $\mathrm{Na}_{2} \mathrm{O}$ & 3.26 & 3.21 & 2.68 & 2.95 & 2.72 & 2.92 & 2.54 & 2.56 & 2.37 & 1.88 & 2.03 & 1.85 \\
\hline $\mathrm{K}_{2} \mathrm{O}$ & 0.07 & 0.08 & 0.05 & 0.03 & 0.05 & 0.05 & 0.07 & 0.03 & 0.04 & 0.04 & 0.05 & 0.03 \\
\hline $\mathrm{P}_{2} \mathrm{O}_{5}$ & 0.15 & 0.14 & 0.11 & 0.05 & 0.09 & 0.12 & 0.10 & 0.07 & 0.09 & 0.04 & 0.11 & 0.06 \\
\hline LOI & 0.21 & 0.27 & 0.24 & 0.38 & 0.35 & 0.35 & 0.25 & 0.28 & 0.52 & 2.03 & 0.65 & 1.01 \\
\hline TOT & 99.42 & 99.58 & 100.22 & 99.04 & 100.30 & 99.41 & 99.39 & 100.22 & 100.47 & 99.48 & 100.36 & 99.91 \\
\hline Mg\# & 0.64 & 0.68 & 0.78 & 0.78 & 0.78 & 0.78 & 0.81 & 0.79 & 0.77 & 0.84 & 0.85 & 0.85 \\
\hline \multicolumn{13}{|c|}{ Trace elements (ppm) } \\
\hline $\mathrm{Sc}$ & 37.0 & 33.8 & 42.8 & 5.2 & 39.3 & 34.9 & 41.4 & 39.0 & 34.6 & 16.1 & 32.3 & 31.5 \\
\hline $\mathrm{Cr}$ & 75 & 96 & 110 & 18 & 312 & 131 & 160 & 128 & 493 & 975 & 1750 & 1877 \\
\hline Co & 38.0 & 36.1 & 38.6 & 39.4 & 32.4 & 31.7 & 38.6 & 38.8 & 46.3 & 40.2 & 29.1 & 37.7 \\
\hline $\mathrm{Ni}$ & 93 & 146 & 134 & 225 & 115 & 106 & 122 & 127 & 202 & 342 & 192 & 247 \\
\hline $\mathrm{La}$ & 3.0 & 2.6 & 0.43 & 0.34 & 0.43 & 0.40 & 0.24 & 0.24 & 0.70 & 0.30 & 0.29 & 0.42 \\
\hline $\mathrm{Ce}$ & 11.0 & 8.8 & 1. & 1.1 & 1.6 & 1.3 & 1.1 & 0.74 & 2.7 & 0.90 & 1.3 & 1.2 \\
\hline $\mathrm{Nd}$ & 10.5 & 8.3 & 1.8 & 0.8 & 1.9 & 1.7 & 1.4 & 1.3 & 2.4 & 1.0 & 1.7 & 1.7 \\
\hline $\mathrm{Sm}$ & 3.7 & 2.84 & 0.93 & 0.31 & 0.83 & 0.71 & 0.65 & 0.66 & 1.05 & 0.40 & 0.68 & 0.61 \\
\hline $\mathrm{Eu}$ & 1.62 & 1.41 & 0.59 & 0.39 & 0.56 & 0.53 & 0.43 & 0.47 & 0.54 & 0.33 & 0.39 & 0.39 \\
\hline $\mathrm{Tb}$ & 0.94 & 0.72 & 0.29 & 0.064 & 0.26 & 0.21 & 0.20 & 0.20 & 0.28 & 0.11 & 0.18 & 0.17 \\
\hline $\mathrm{Yb}$ & 3.6 & 2.8 & 1.07 & 0.23 & 0.94 & 0.79 & 0.78 & 0.75 & 1.06 & 0.39 & 0.67 & 0.66 \\
\hline $\mathrm{Lu}$ & 0.51 & 0.42 & 0.18 & 0.042 & 0.15 & 0.12 & 0.12 & 0.13 & 0.1 & 0.057 & 0.11 & 0.10 \\
\hline $\mathrm{Hf}$ & 1.47 & 1.70 & 0.40 & 0.14 & 0.35 & 0.28 & 0.22 & 0.23 & 0.64 & 0.19 & 0.37 & 0.30 \\
\hline $\mathrm{Ta}$ & 0.081 & 0.072 & $<0.005$ & $<0.005$ & $<0.005$ & $<0.02$ & $<0.02$ & $<0.005$ & 0.045 & $<0.005$ & $<0.005$ & cont \\
\hline
\end{tabular}

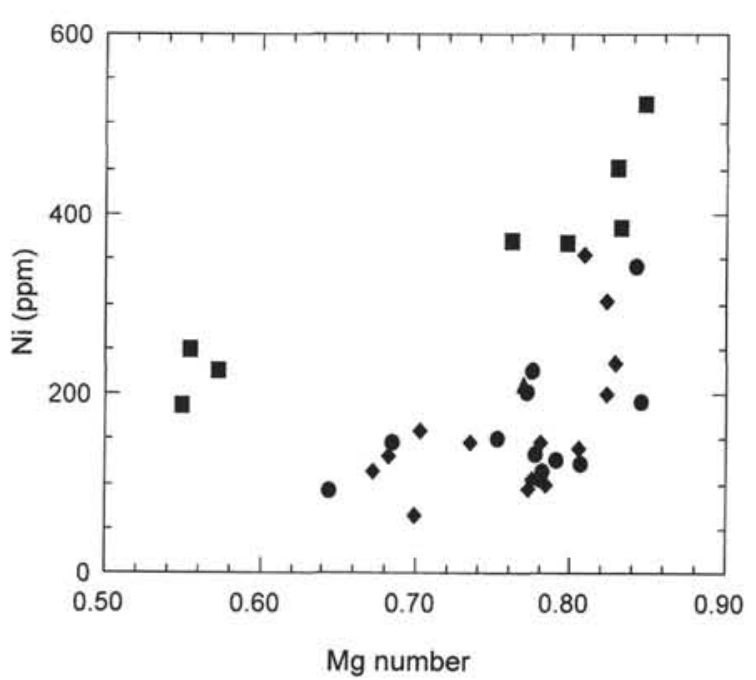

Figure $1 \mathrm{Ni}$ contents and calculated $\mathrm{Mg}$ numbers of the samples studied. $\mathrm{Mg}$ numbers are the molar ratio $\mathrm{Mg} /(\mathrm{Mg}+0.85 \times \mathrm{FeTot})$. Triangle $=$ Hole $920 \mathrm{D}$; diamonds $=$ Holes $921 \mathrm{~B}, 921 \mathrm{C}$, and $921 \mathrm{E}$; squares $=$ Holes $922 \mathrm{~A}$ and 922B ; circles $=$ Hole 923A . The selected samples cover the range of a large number of shipboard analyses (Cannat, Karson, Miller, et al., 1995). The evolved samples are the oxide gabbros from Holes 922A and 922B.

ited by the larger set analyzed in the shipboard laboratory. With the exception of the minor occurrences of oxide-rich gabbro, the MARK gabbros are all rather primitive in terms of major-element composition (e.g., Mg\# = 67-85).

The chondrite-normalized REE patterns of the individual samples are displayed in Figure 2. One should notice that the vertical scale of Figure 2C (Holes 922A and 922B) differs from the uniform scale of the REE plots of samples from the other holes. The trace-element contents, in particular of the REE, do show substantial variation that is mainly related to the cumulate mineralogy of the samples.

Gabbros from Holes 921B and 923A range in lithology from early troctolitic cumulates to gabbros (sensu stricto). These lithologies have similar REE characteristics in both Holes (Figs. 2B, 2D) The troctolites are characterized by low REE concentrations and flat chondrite-normalized REE patterns with large positive europium anomalies, reflecting the dominant contribution of REE from plagioclase in these rocks. The gabbros (sensu stricto) have higher REE concentrations and exhibit light-REE-depleted, chondrite-normalized REE patterns with less prominent europium anomalies, characteristics that reflect the presence of clinopyroxene in these cumulates.

Based on cross-hole correlations, the majority of gabbros recovered from Hole $921 \mathrm{E}$ are interpreted as stratigraphically underlying those recovered in Hole 921B (Cannat, Karson, Miller, et al., 1995). Troctolites are rare in Hole $921 \mathrm{E}$, and gabbro and olivine gabbro, similar in REE characteristics to samples from Holes 921B and $923 \mathrm{~A}$, are the dominant lithologies. Occasional gabbronoritic rocks occur toward the bottom of Hole 921E. They have smaller europium anomalies and higher REE concentrations than the gabbros (sensu stricto). Because the concentrations largely overlap those of the diabases, the gabbronoritic rocks may represent liquid compositions.

Gabbros from Site 922 exhibit a bimodal distribution in REE characteristics. On the one hand, we have troctolites and olivine gabbros, which, in comparison to similar lithologies from Sites 921 and 923 , are characterized by much higher REE concentrations and smaller positive europium anomalies (Fig. 2C). On the other hand, we have evolved oxide-rich gabbros in which REE concentrations are extremely high, and in which chondrite-normalized REE patterns have negative europium anomalies (Fig. 2C). The minor, localized occurrences of oxide-rich gabbros suggest that they may have crystallized from pods of evolved residual liquid. Apatite is a conspicuous accessory mineral in the oxide-rich gabbros (Cannat, Karson, Miller, et al., 1995). Presumably, apatite accounts for the high $\mathrm{P}_{2} \mathrm{O}_{5}$ contents (Table 1), and contributes substantially to the REE enrich- 

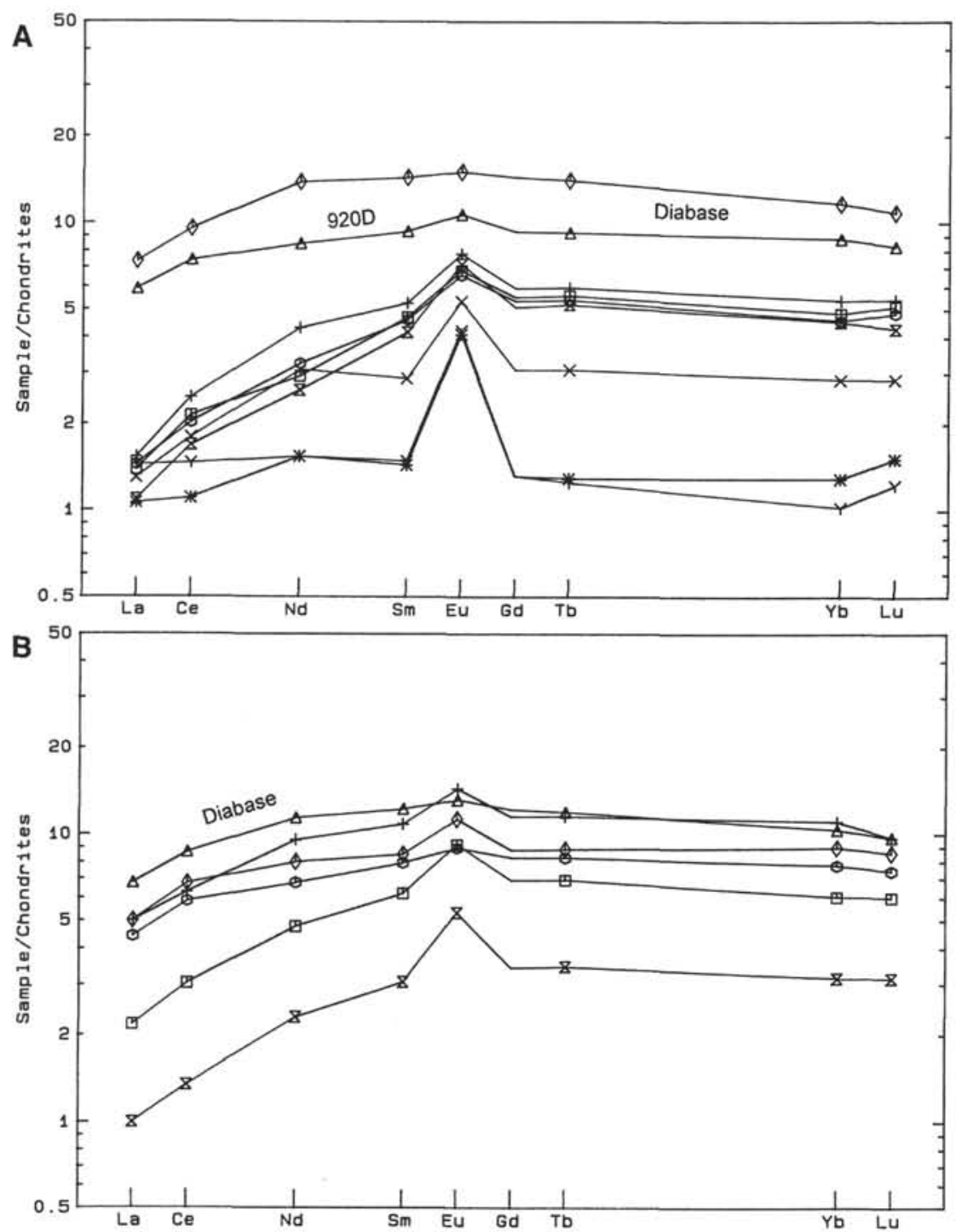

Figure 2. A. Chondrite-normalized REE patterns of samples from Holes 920D and 921B. The two REE-enriched samples are the diabase Samples 153-920D-9R-2, 33$38 \mathrm{~cm}$, and 153-921B-1W-2, 10-14 cm. B. Chondritenormalized REE patterns of samples from Holes 921C and 921E. The diabase sample is Sample 153-921C-2R$1,16-22 \mathrm{~cm}$. ment. Fractionation of REE from Hf by apatite probably accounts also for the low Hf/REE ratios of the oxide-rich gabbros from Site 922 .

\section{$\mathrm{Sr}, \mathrm{Nd}$, and $\mathrm{Pb}$ Isotopes}

$\mathrm{Sr}-, \mathrm{Nd}-$, and $\mathrm{Pb}$-isotope ratios for leached residues of 19 gabbros, a diabase, and the GABY standard are presented in Table 2 and Figure 3 , together with data for unleached aliquots of powder for a range of gabbroic (sensu lato) compositions from Site 921 and the GABY standard.

The unleached GABY standard gave the highest ${ }^{87} \mathrm{Sr}{ }^{86} \mathrm{Sr},{ }^{206} \mathrm{~Pb} /$ ${ }^{204} \mathrm{~Pb},{ }^{207} \mathrm{~Pb} /{ }^{204} \mathrm{~Pb}$, and ${ }^{208} \mathrm{~Pb} /{ }^{204} \mathrm{~Pb}$ ratios of the six unleached samples (Table 2). It was, therefore, considered a good test for our leaching technique. For both isotopic systems, the residue, after leaching by our standard method, lies within the cluster of leached gabbro samples. However, after leaching in hot 6-M HCl, the residue still had an elevated ${ }^{87} \mathrm{Sr} /{ }^{86} \mathrm{Sr}$ value, and $\mathrm{Nd}$ and $\mathrm{Pb}$ had been so strongly depleted as to render their measurement extremely difficult.

For the gabbro samples, leaching resulted in smaller shifts in the isotope ratios than for the GABY standard. These shifts are almost within the error of the measurements. However, the leached residues give consistently lower ${ }^{87} \mathrm{Sr} /{ }^{86} \mathrm{Sr}$ and $\mathrm{Pb}$-isotope ratios and higher
${ }^{143} \mathrm{Nd} /{ }^{144} \mathrm{Nd}$ ratios than the unleached gabbros, as do the duplicated, but more thorough, leaches performed at KU (Table 2); the shift is therefore believed to be real. These results suggest that leaching removes a presumably secondary component, which, relative to MARK gabbros, has radiogenic $\mathrm{Sr}$ and $\mathrm{Pb}$, and unradiogenic $\mathrm{Nd}$. The reproducibility of the isotopic results after leaching gives us confidence that in most cases our leaching process has eliminated all, or nearly all, traces of secondary $\mathrm{Sr}, \mathrm{Nd}$, and $\mathrm{Pb}$.

$\mathrm{Sr}-, \mathrm{Nd}-$, and $\mathrm{Pb}$-isotopic compositions for leached gabbros from Sites 921 and 923 exhibit a very restricted range of values: ${ }^{87} \mathrm{Sr} /{ }^{86} \mathrm{Sr}$ $=0.70234-0.70239 ;{ }^{143} \mathrm{Nd} /{ }^{144} \mathrm{Nd}=0.51324-0.51319 ;{ }^{206} \mathrm{~Pb} /{ }^{204} \mathrm{~Pb}=$ $18.02-18.07 ;{ }^{207} \mathrm{~Pb} /{ }^{204} \mathrm{~Pb}=15.42-15.47$; and ${ }^{208} \mathrm{~Pb} / 204 \mathrm{~Pb}=37.37-$ 37.54 (Fig. 3). These values are typical of MORB and lie towards the depleted extreme of values for Atlantic MORB (Fig. 3 insets). However, although Site 922 gabbros have similar $\mathrm{Nd}$ - and $\mathrm{Pb}$-isotope compositions to the other samples, their ${ }^{87} \mathrm{Sr} /{ }^{86} \mathrm{Sr}$ ratios are more variable (oxide-rich gabbros ${ }^{87} \mathrm{Sr} /{ }^{86} \mathrm{Sr}=0.70235-0.70241$; olivine gabbros and troctolites ${ }^{87} \mathrm{Sr} /{ }^{86} \mathrm{Sr}=0.70239-0.70251$ ), and at a given ${ }^{206} \mathrm{~Pb} / 204 \mathrm{~Pb}$ ratio they have lower ${ }^{207} \mathrm{~Pb} /{ }^{204} \mathrm{~Pb}$ and ${ }^{208} \mathrm{~Pb} /{ }^{204} \mathrm{~Pb}$ ratios than Site 921 and 923 gabbros.

For all five pairs of variably deformed and recrystallized gabbros, the majority of $\mathrm{Sr}-$, $\mathrm{Nd}$-, and $\mathrm{Pb}$-isotope ratios for each pair are identical, within error. The Site 921 diabase has more radiogenic $\mathrm{Sr}\left({ }^{87} \mathrm{Sr} /\right.$ 
Figure 2 (continued). C. Chondrite-normalized REE patterns of samples from Holes $922 \mathrm{~A}$ and $922 \mathrm{~B}$. Note that the vertical scale is different from that used in the other REE diagrams. The group of the samples at the top of figure are the oxide gabbros. The group in the lower part are troctolites. Oxide gabbros and troctolites from the two holes appear to be indistinguishable. D. Chondritenormalized REE patterns of samples from Hole 923A. The two enriched patterns represent subsamples of oxide gabbro from Sample 153-923A-2R-2, 23-30 cm, that differ in grain size; the coarse-grained sample has the higher REE content.
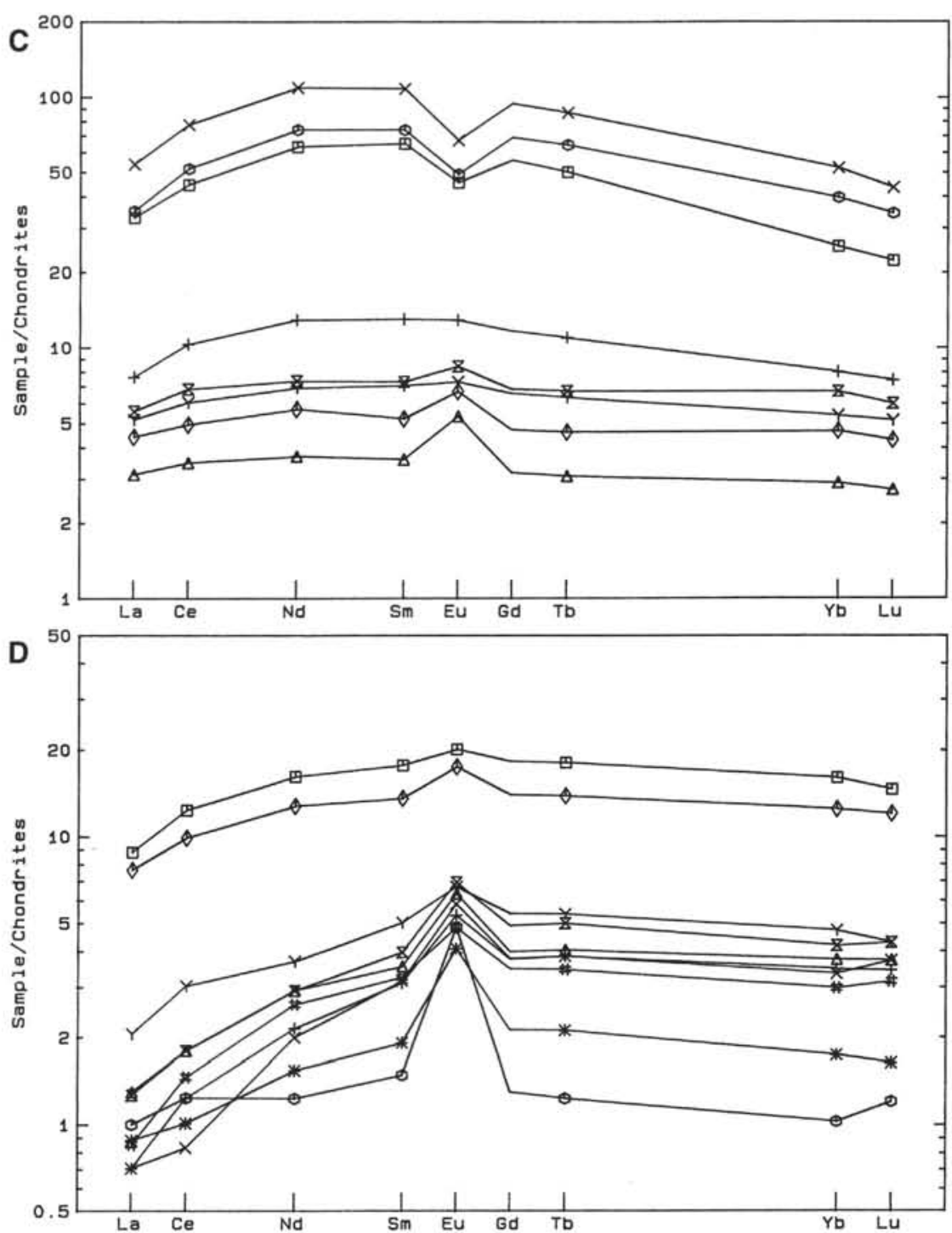

$\left.{ }^{86} \mathrm{Sr}=0.70243\right)$ and $\mathrm{Pb}$ - (e.g., $\left.{ }^{206} \mathrm{~Pb} /{ }^{204} \mathrm{~Pb}=18.12\right)$ isotope ratios than Site 921 and 923 gabbros, but its ${ }^{143} \mathrm{Nd} /{ }^{144} \mathrm{Nd}(0.513221)$ is within the range of values for all gabbros.

\section{DISCUSSION}

\section{The Parental Magma of the Cumulate Rocks}

The three diabase samples analyzed (Samples 153-920D-9R-2, $33-38 \mathrm{~cm}, 153-921 \mathrm{~B}-1 \mathrm{~W}-2,10-14 \mathrm{~cm}$, and 153-921C-2R-1, 16$22 \mathrm{~cm}$ ) have REE patterns and concentrations that resemble liquid compositions. They are, thus, potential candidates for parental magma compositions for the cumulate rocks. Another sample that closely resembles a liquid composition in terms of REE is the moderately evolved gabbronorite Sample 153-923A-2R-2, 23-30 cm (the two REE-enriched subsamples shown in Fig. 2D). The few basalt samples recovered from Holes 669A and 648B (ODP Legs 106 and 109, also in the MARK area) have similar REE characteristics to our diabase composition (Detrick, Honnorez, Bryan, Juteau, et al., 1988; Di Donato et al., 1990). It therefore appears that the parental magma south of the Kane Fracture Zone was a rather homogeneous, moderately depleted, normal MORB. In the discussion that follows, it will be assumed that the average composition of Samples 153-921B-1W$2,10-14 \mathrm{~cm}$, and $153-921 \mathrm{C}-2 \mathrm{R}-1,16-22 \mathrm{~cm}$, is the best available estimate of the composition of the parental magma of the Leg 153 plu- tonic suite. The diabase sample from Hole 920D and the two Hole 923 A gabbronorites have not been included in the average because their slight positive $\mathrm{Eu}$ anomalies are indicative of substantial amounts of cumulate plagioclase.

\section{Modeling of REE Geochemistry}

A cogenetic series of gabbroic rocks exhibits a large variety of REE patterns. The reasons are that (1) the four main phases involved in the make-up of the rocks-plagioclase, olivine, clinopyroxene, and intercumulus liquid-have very different affinities for the REE, (2) plagioclase prefers light REE over heavy REE, whereas the reverse holds for clinopyroxene, and (3) plagioclase preferentially concentrates $\mathrm{Eu}^{2+}$ relative to the other trivalent REE cations (Lipin and McKay, 1989, and references therein). As a result, variations in modal abundances of the four phases that cause only moderate variation in the major-element composition of the rocks are greatly amplified in the REE geochemistry. Figure 4 summarizes the REE systematics of the Leg 153 gabbros (sensu lato) and diabases. The samples from Holes 922A and 922B have been de-emphasized (by choosing open symbols) in this figure because they underwent a more complex and rather peculiar petrogenetic evolution, as will be demonstrated in a later section of the discussion. Figure 5 compares the observed variation of $\mathrm{La}$ and $\mathrm{Yb}$ contents and ratios to the results of model calculations. The adopted model is the most simple one: it is assumed that 
Table 2. Sr-, Nd-, and $\mathrm{Pb}$-isotope ratios for gabbros and diabase from Sites 921, 922, and 923.

\begin{tabular}{|c|c|c|c|c|c|c|c|c|}
\hline $\begin{array}{l}\text { Core, section, } \\
\text { interval }(\mathrm{cm})\end{array}$ & LU & $\begin{array}{c}\text { LOI } \\
(w t \%)\end{array}$ & $\begin{array}{c}\text { Residue } \\
(\%)\end{array}$ & ${ }^{87} \mathrm{Sr} /{ }^{86} \mathrm{Sr} 2 \sigma(\mathrm{m})$ & ${ }^{143} \mathrm{Nd} /{ }^{144} \mathrm{Nd} 2 \sigma(\mathrm{m})$ & ${ }^{206} \mathrm{~Pb} /{ }^{204} \mathrm{~Pb}$ & ${ }^{207} \mathrm{~Pb} /{ }^{204} \mathrm{~Pb}$ & ${ }^{208} \mathrm{~Pb} /{ }^{204} \mathrm{~Pb}$ \\
\hline \multicolumn{9}{|l|}{ 153-921B- } \\
\hline $1 \mathrm{~W}-2,10-14$ & 2 & 2.39 & Unleached & $0.702490 \pm 10$ & $0.513201 \pm 8$ & 18.132 & 15.462 & 37.530 \\
\hline (diabase) & & & $\begin{array}{l}\mathrm{n} / \mathrm{a} \\
46^{*}\end{array}$ & $\begin{array}{l}0.702466 \pm 11 \\
0.702430 \pm 11\end{array}$ & $\begin{array}{l}0.513206 \pm 8 \\
0.513221 \pm 11\end{array}$ & 18.124 & 15.459 & 37.518 \\
\hline \multirow[t]{2}{*}{$3 R-1,20-27$} & 3 & 0.32 & 79 & $0.702388 \pm 10$ & $0.513186 \pm 34$ & $\uparrow 18.017$ & 15.431 & 37.384 \\
\hline & & & $62 *$ & $0.702379 \pm 8$ & $0.513225 \pm 5$ & & & \\
\hline \multirow{3}{*}{$3 R-1,140-144$} & 3 & 0.39 & Unleached & $0.702402 \pm 13$ & & 18.160 & 15.549 & 37.772 \\
\hline & & & 87 & $0.702381 \pm 25$ & $0.513203 \pm 29$ & 18.071 & 15.467 & 37.511 \\
\hline & & & $74 *$ & $0.702360 \pm 8$ & $0.513223 \pm 25$ & 18.068 & 15.462 & 37.498 \\
\hline \multirow[t]{2}{*}{$4 R-2,30-36$} & 4 & 1.04 & Unleached & $0.702407 \pm 7$ & $0.513189 \pm 14$ & & & \\
\hline & & & 71 & $0.702335 \pm 18$ & $0.513204 \pm 14$ & 18.053 & 15.444 & 37.442 \\
\hline \multirow[t]{2}{*}{$4 R-3,6-12$} & 4 & 1.23 & $\begin{array}{l}\text { Unleached } \\
69\end{array}$ & $\begin{array}{l}0.702400 \pm 10 \\
0.702374+10\end{array}$ & $0.513216 \pm 20$ & & & \\
\hline & & & $\begin{array}{l}69 \\
46^{*}\end{array}$ & $0.702368 \pm 10$ & $0.513210 \pm 14$ & & & \\
\hline \multicolumn{9}{|l|}{$153-921 \mathrm{E}-$} \\
\hline $2 \mathrm{R}-2,44-50$ & 1 & 0.23 & 83 & $0.702368 \pm 8$ & $0.513192 \pm 43$ & 18.044 & 15.460 & 37.467 \\
\hline $3 R-1,30-36$ & $1 / 2$ & 0.39 & 82 & $0.702367 \pm 8$ & $0.513194 \pm 14$ & 18.071 & 15.461 & 37.490 \\
\hline \multirow{2}{*}{$8 R-2,32-40$} & 3 & 0.33 & Unleached & $0.702402 \pm 14$ & $0.513195 \pm 9$ & 18.141 & 15.588 & 37.967 \\
\hline & & & 96 & $0.702340 \pm 22$ & $0.513212 \pm 10$ & 18.050 & 15.446 & 37.443 \\
\hline \multicolumn{9}{|l|}{ 153-922A- } \\
\hline $2 R-3,37-44$ & 2 & 1.29 & $32 *$ & $0.702459 \pm 11$ & $0.513221 \pm 6$ & 18.077 & 15.445 & 37.441 \\
\hline $3 R-1,94-100$ & 2 & 0.66 & 54 & $0.702389 \pm 8$ & $0.513206 \pm 17$ & 18.075 & 15.435 & 37.440 \\
\hline \multicolumn{9}{|l|}{$153-922 \mathrm{~B}-$} \\
\hline $1 \mathrm{~W}-1,86-91$ & 1 & 1.23 & $29 *$ & $0.702394 \pm 11$ & $0.513225 \pm 18$ & 18.107 & 15.472 & 37.536 \\
\hline $1 \mathrm{~W}-1,109-115$ & i & 0.85 & $43^{*}$ & $0.702347 \pm 24$ & $0.513220 \pm 5$ & 18.117 & 15.483 & 37.571 \\
\hline $2 \mathrm{R}-2,71-80$ & 1 & 1.06 & 61 & $0.702410 \pm 8$ & $0.513193 \pm 14$ & 18.058 & 15.418 & 37.386 \\
\hline \multirow{2}{*}{$3 \mathrm{R}-1,37-43$} & 2 & 2.3 & 46 & $0.702493 \pm 14$ & $0.513223 \pm 53$ & 18.055 & 15.448 & 37.449 \\
\hline & & & $19^{*}$ & $0.702511 \pm 10$ & $0.513223 \pm 6$ & 18.091 & 15.460 & 37.451 \\
\hline \multicolumn{9}{|l|}{$153-923 \mathrm{~A}-$} \\
\hline \multirow[t]{2}{*}{$2 \mathrm{R}-1,22-24$} & 1 & 0.6 & 80 & $0.702382 \pm 10$ & $0.513207 \pm 15$ & $† 18.034$ & 15.413 & 37.371 \\
\hline & & & $64 *$ & $0.702370 \pm 10$ & $0.513218 \pm 17$ & 18.073 & 15.464 & 37.538 \\
\hline \multirow{2}{*}{$5 R-1,39-45$} & 1 & 0.24 & 87 & $0.702373 \pm 10$ & & $\uparrow 18.016$ & 15.464 & 37.516 \\
\hline & & & $71 *$ & $0.702380 \pm 8$ & $0.513230 \pm 6$ & 18.036 & 15.456 & 37.443 \\
\hline $2 \mathrm{R}-2,23-30$ (coarse) & 1 & 0.21 & $72 *$ & $0.702361 \pm 10$ & $0.513231 \pm 6$ & 18.053 & 15.466 & 37.491 \\
\hline $2 R-2,23-30$ (fine) & 1 & 0.27 & $48^{*}$ & $0.702362 \pm 10$ & $0.513212 \pm 9$ & 18.043 & 15.454 & 37.443 \\
\hline $11 \mathrm{R}-1,48-55$ (coarse) & 2 & 0.35 & $64 *$ & $0.702374 \pm 10$ & $0.513237 \pm 6$ & & & \\
\hline $11 \mathrm{R}-1,48-55$ (fine) & 2 & 0.25 & $53^{*}$ & $0.702391 \pm 10$ & $0.513230 \pm 8$ & 18.030 & 15.439 & 37.400 \\
\hline \multicolumn{9}{|l|}{ GABY } \\
\hline \multirow{3}{*}{\multicolumn{2}{|c|}{$\begin{array}{l}\text { Shipboard gabbro standard } \\
\text { Hot leach in 6-M HCl } \\
\text { Ultrasonic leach in 6-M HCl }\end{array}$}} & 1.01 & Unleached & $0.702628 \pm 15$ & $0.513241 \pm 16$ & 18.570 & 15.625 & 38.448 \\
\hline & & & 65 & $0.702492 \pm 17$ & $0.513285 \pm 86$ & & & \\
\hline & & & 65 & $0.702368 \pm 13$ & $0.513212 \pm 26$ & 18.072 & 15.478 & 37.523 \\
\hline
\end{tabular}

Notes: $\mathrm{LU}=\mathrm{Lithologic}$ Unit; $\mathrm{LOI}=$ loss on ignition; $\mathrm{n} / \mathrm{a}=$ not analyzed; $2 \sigma(\mathrm{m})=$ two standard deviations of the mean; * $=$ chemistry and Sr- and Nd-isotope measurements done at the Dansk Center for Isotopgeologi, Københavns Universitet; $\dagger=\mathrm{Pb}$-isotope measurements at $1250^{\circ} \mathrm{C}$ (see "Analytical Methods" section, this chapter).

the troctolitic rocks and gabbros (sensu stricto) consist of a fairly primitive cumulate fraction and variable amounts of trapped intercumulus liquid represented by the average parental liquid mentioned above. Figure 5 shows the samples from all the studied holes except Holes $922 \mathrm{~A}$ and 922B. The open circles represent model end-members and rock types. They have been calculated using the following partition coefficients: $\mathrm{La}$ (olivine) $=0.01, \mathrm{La}$ (plagioclase) $=0.06$, and $\mathrm{La}($ clinopyroxene $)=0.04 ; \mathrm{Yb}($ olivine $)=0.02, \mathrm{Yb}$ (plagioclase $)=$ 0.02 , and $\mathrm{Yb}$ (clinopyroxene $)=0.4$. These estimates are based on data for basaltic liquids culled from various literature sources. The model gabbro composition $6 / 4 \mathrm{Gab}$ stands for a $(60 \%$ plagioclase $) /(40 \%$ clinopyroxene) cumulate. The presence of $10 \%$ to $20 \%$ modal olivine in olivine gabbros has a minor effect on the REE mass balance and has been neglected. The two troctolite end-member compositions represent $80 \% / 20 \%$ and $70 \% / 30 \%$ plagioclase/olivine mixtures. The dashed tie-line between plagioclase and clinopyroxene shows the expected composition of pure adcumulates formed in equilibrium with the parental liquid. Meso- and orthocumulate troctolitic or gabbroic (sensu stricto) rocks should lie on the two mixing curves (full lines with crosses). The crosses mark trapped liquid values of $5 \%, 10 \%$, $15 \%, 20 \%, 30 \%, 40 \%, 60 \%$, and $80 \%$. The calculations suggest that many of the analyzed samples originally contained at least $5 \%$ to $15 \%$ trapped intercumulus melt. A substantial fraction of the gabbros can be interpreted as the plutonic equivalents of moderately phyric liquids ( $70 \%$ to $80 \%$ liquid). The model further demonstrates that even small amounts of trapped intercumulus liquids greatly affect the trace-element composition of troctolitic rocks.

The analyzed samples from Sites 921 and 923 do indeed converge toward a common parental liquid composition, as assumed in the model. However, it is significant that most of gabbros plot to the right of the mixing line. A better fit between observations and model could be achieved by using another set of partition coefficient data, a parental liquid with higher $\mathrm{Yb}$ content, a slightly lower plagioclase/clinopyroxene ratio, a range of liquid compositions that would expand end-member points into fields and mixing lines into mixing bands, etc. But none of these changes offers a really satisfactory solution. It is evident that the simple model illustrated in Figure 5 can only explain the first-order REE variations in the samples. Its chief merit is that it points to the importance of more complex processes attending adcumulus growth and compaction of the cumulus pile (Lesher and Walker, 1988; Langmuir, 1989). Because, for the adopted values of partition coefficients, the bulk distribution coefficients for a $60 / 40$ plagioclase/clinopyroxene assemblage are 0.05 for $\mathrm{La}$ and 0.17 for $\mathrm{Yb}$, the displacement of the sample data to the right of the mixing line most likely reflects the preferential retention of heavy REE in the adcumulus or intercumulus crystals and the higher extent to which light REE are expelled with the residual fluids of an open-system adcumulus growth process.

Additional evidence for fractionation caused by adcumulus growth derives from the Sm-Eu systematics of troctolites and gabbros from Sites 921 and 923 . Figure 6 shows the observed and modeled chondrite-normalized $\mathrm{Sm}$ abundances and $\mathrm{Eu} / \mathrm{Sm}$ ratios. The latter ratio is a convenient proxy for the Eu anomaly, because in the absence of Eu anomalies the Eu/Sm ratios of normal MORB and related gabbroic rocks should not differ much from the chondritic value. The adopted partition coefficients are $\mathrm{Sm}$ (olivine) $=0.01$, Sm(plagioclase $)=0.03$, and $\mathrm{Sm}$ (clinopyroxene $)=0.2 ; \mathrm{Eu}($ olivine $)=0.01$, $\operatorname{Eu}($ plagioclase $)=0.3$, and Eu(clinopyroxene $)=0.2$. The plagioclase 

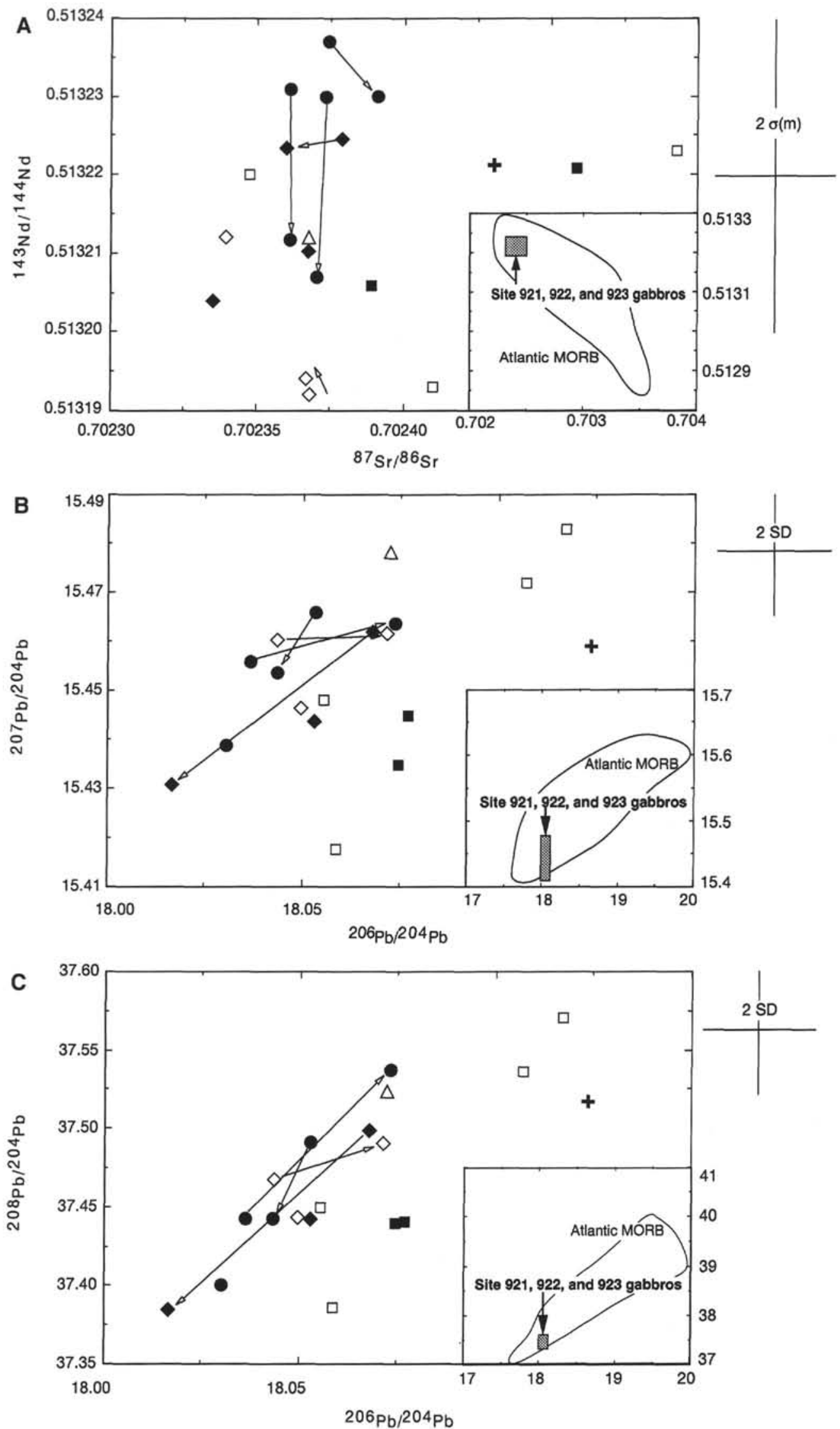

Figure 3. Sr-, Nd-, and Pb-isotopic compositions for Site 921 , 922, and 923 gabbros. A. ${ }^{143} \mathrm{Nd} /{ }^{144} \mathrm{Nd}$ vs. ${ }^{87} \mathrm{Sr} /{ }^{86} \mathrm{Sr} . \mathbf{B} .{ }^{207} \mathrm{~Pb} /{ }^{204} \mathrm{~Pb}$ vs. ${ }^{206} \mathrm{~Pb} /{ }^{204} \mathrm{~Pb} . \mathbf{C} .{ }^{208} \mathrm{~Pb} / 204 \mathrm{~Pb}$ vs. ${ }^{206} \mathrm{~Pb} /{ }^{204} \mathrm{~Pb}$. Solid diamonds = Hole 921B; open diamonds = Hole 921E; solid squares = Hole 922A; open squares = Hole 922B; solid circles = Hole 923A; cross $=$ diabase from Hole $921 \mathrm{~B}$; open triangle $=\mathrm{GABY}$. Arrows connect less-deformed or undeformed gabbros to deformed gabbros. The insets compare our data with the field for Atlantic MORB. 


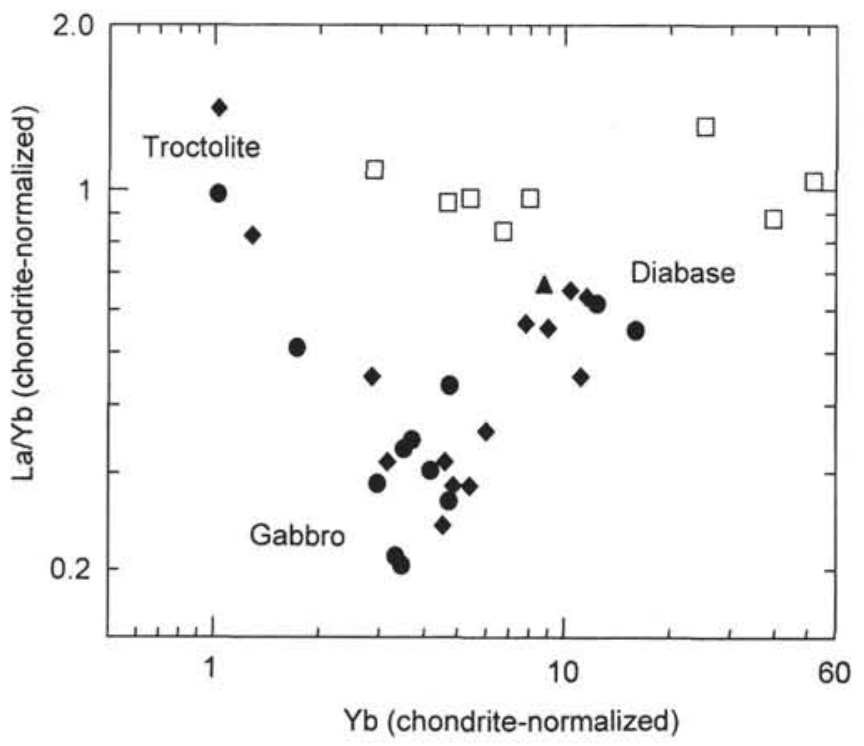

Figure 4. Variation of chondrite-normalized $\mathrm{La} / \mathrm{Yb}$ ratio and $\mathrm{Yb}$ contents. Open squares are the samples from Holes 922A and 922B. Other symbols are the same as in Figure 1.

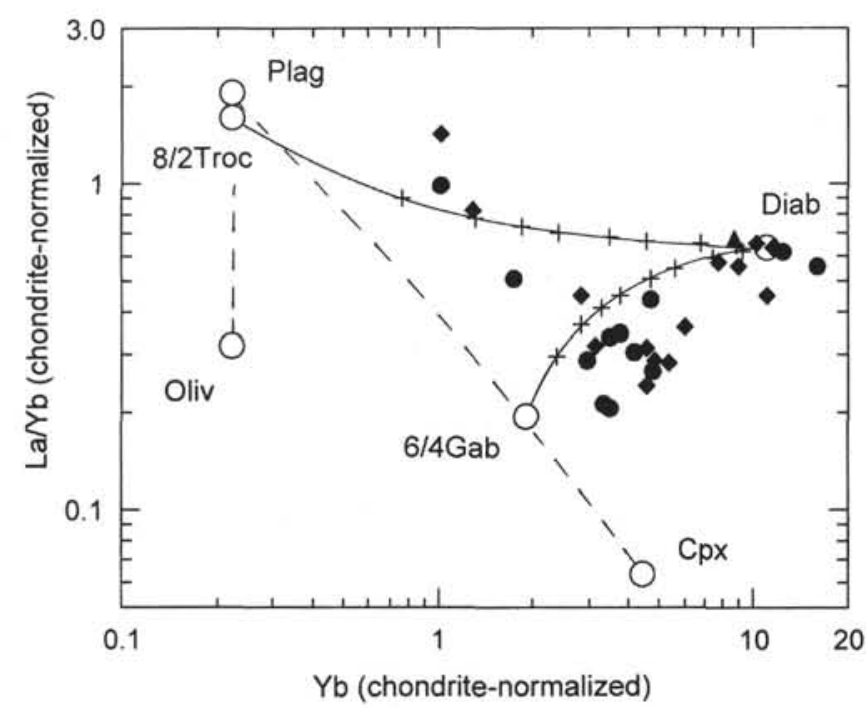

Figure 5. Modeling of light REE (La) and heavy REE (Yb) systematics of samples from Holes 920D, 921B, 921C, 921E, and 923A by mixing of primitive adcumulates with trapped intercumulus parental liquid, represented by the diabase samples from Holes 921B and 921C. Plagioclase (Plag), olivine (Oliv), and clinopyroxene ( $\mathrm{Cpx}$ ) end-members are plagioclase, olivine, and clinopyroxene in equilibrium with the parental liquid. "Troc" and "6/4Gab" are the compositions of model cumulates consisting of $(80 \%-70 \%$ plagioclase $) /(20 \%-30 \%$ olivine $)$ and $(60 \%$ plagioclase $) /(40 \%$ clinopyroxene $)$ assemblages. Diab $=$ diabase. The dashed lines are mixing lines between plagioclase-olivine and plagioclase-clinopyroxene end-members. The solid lines with crosses are mixing curves between the model parental liquid and "Troc" or " $6 / 4 \mathrm{Gab}$ " modal assemblages. Crosses mark 5\%, 10\%, 15\%, 20\%, $30 \%, 40 \%, 60 \%$, and $80 \%$ trapped intercumulus liquid. Sample symbols are the same as in Figure 1.

partition coefficient of Eu is obviously the critical parameter of the model. The chosen value of 0.3 is based on data for calcic plagioclase from experimental and natural basaltic systems (Schnetzler and Philpotts, 1970; Sun et al., 1974; Drake, 1975). The olivine, plagioclase, and troctolite end-members have very high $\mathrm{Eu} / \mathrm{Sm}$ ratios or low $\mathrm{Sm}$ contents; they have not been included in Figure 6 to maintain a

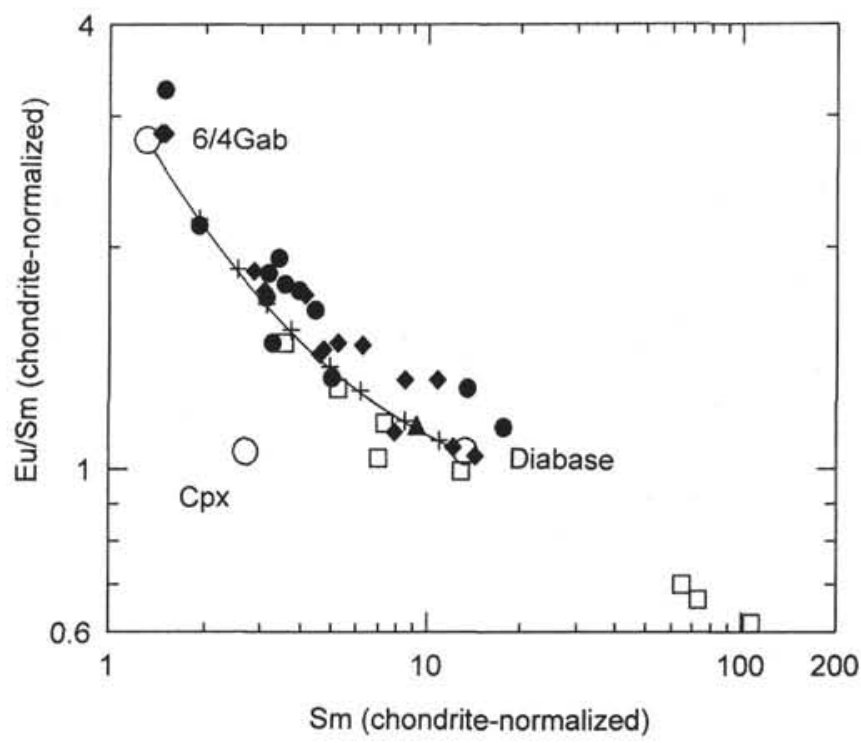

Figure 6. Modeling of Eu/Sm vs. Sm variation trends; all data are chondritenormalized. The Eu/Sm is a proxy for the Eu anomaly. Open squares are the samples from Site 922. Other symbols are the same as in Figure 1.

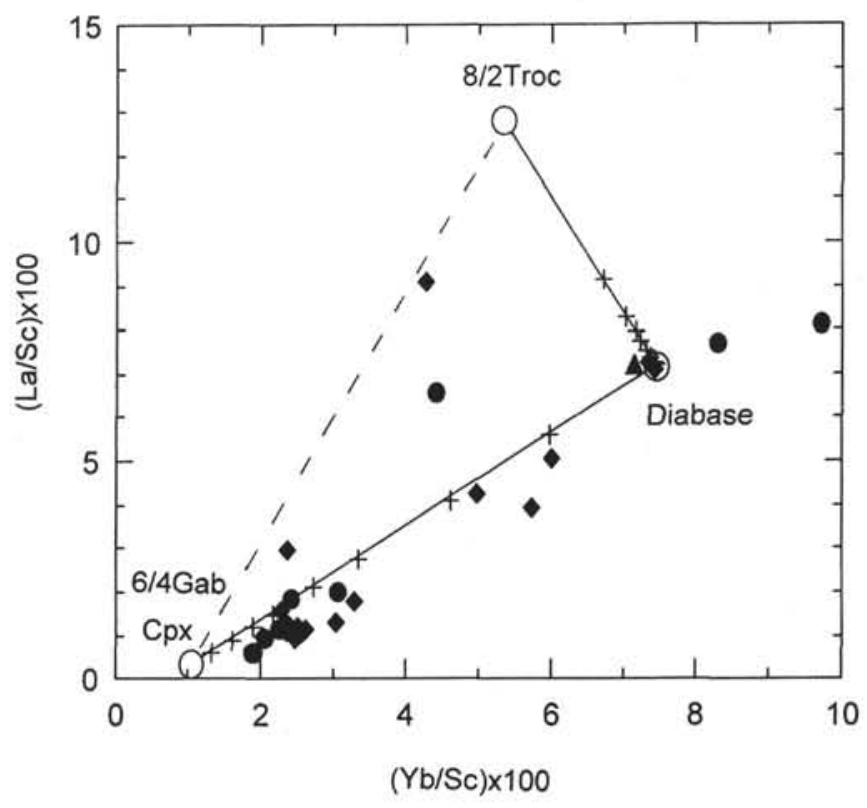

Figure 7. $\mathrm{La} / \mathrm{Sc}$ vs. $\mathrm{Yb} / \mathrm{Sc}$ mixing diagrams for samples from Holes $920 \mathrm{D}$, 921B, 921C, 921E, and 923A. Abbreviations, mixing curves, and symbols are the same as in Figure 5.

sufficient resolution of the sample data points. The troctolite-diabase and 6/4Gab-diabase mixing lines largely coincide, and only the latter is plotted. The crosses mark trapped liquid values of $5 \%, 10 \%, 15 \%$, $20 \%, 30 \%, 40 \%, 60 \%$, and $80 \%$. It is noteworthy that most gabbros from Sites 921 and 923 plot above the calculated mixing line. This is a second-order effect expected from adcumulus growth during cumulus pile compaction, because the $\mathrm{Eu} / \mathrm{Sm}$ ratio will increase as a result of preferential retention of Eu relative to $\mathrm{Sm}$ in adcumulus and intercumulus plagioclase.

\section{REE-Scandium Mixing Relations}

Scandium is another trace element that amplifies modal variations in basic plutonic rocks because of its high partition coefficient for cli- 
nopyroxene, as compared to plagioclase and olivine (Sc partition coefficient values adopted in the following discussion are 0.1 for olivine, 0.01 for plagioclase, and 3.0 for clinopyroxene). Because of the substantial variation of $\mathrm{La} / \mathrm{Yb}$ ratios and Sc/REE ratios, these three elements are particularly useful to study mixing relations (Langmuir et al., 1978). Figure 7 shows the variation of $\mathrm{La} / \mathrm{Sc}$ and $\mathrm{Yb} / \mathrm{Sc}$ ratios in all analyzed samples, except those from Site 922 . In such a threeelement ratio plot with common denominators, samples that are related by a binary mixing process should define linear arrays. The endmembers and mixing curves displayed on Figure 7 have been calculated as for the $\mathrm{La} / \mathrm{Yb}$ vs. $\mathrm{Yb}$ and $\mathrm{Eu} / \mathrm{Sm}$ vs. Sm diagrams (Figs. 5, 6). The plagioclase end-member has very high $\mathrm{La} / \mathrm{Sc}$ and $\mathrm{Yb} / \mathrm{Sc}$ ratios and plots off-scale; the $6 / 4 \mathrm{Gab}$ composition lies close to the clinopyroxene end-member. Figure 7 reinforces the conclusions drawn from Figures 5 and 6, namely that intercumulus liquid trapping explains the first-order variations, but that trace-element ratios also have been significantly changed by fractionation during adcumulate growth and cumulate maturation. The two samples that lie to the right of the diabases in Figure 7 are the two subsamples of REE-enriched oxide gabbro, Sample 153-923A-2R-2, 23-30 cm. The position of the samples in this diagram reflects their moderately evolved nature because fractionation of basaltic liquids also enhances the $\mathrm{La} / \mathrm{Sc}$ and $\mathrm{Yb} / \mathrm{Sc}$ ratios. Another indication of the evolved nature of these subsamples is their relatively low $\mathrm{Cr}$ content (Table 1). These two samples further illustrate the complexity of plutonic geochemical fractionation, because the small positive Eu anomalies presumably reflect plagioclase accumulation in pods of evolved liquids.

\section{A Special Case: Holes 922A and 922B}

The $\mathrm{La} / \mathrm{Sc}$ and $\mathrm{Yb} / \mathrm{Sc}$ ratios of the samples from Holes $922 \mathrm{~A}$ and $922 \mathrm{~B}$ are plotted in Figure 8A. The samples in the lower left corner are the troctolites and olivine gabbros, and the samples to the right are the evolved oxide gabbros characterized by high REE abundances and negative Eu anomalies (Fig. 2C). Judged from the high Mg numbers and high $\mathrm{Ni}$ contents, the cumulate minerals of the troctolites must have crystallized from a primitive liquid. Hence, it is remarkable that the troctolites have the high $\mathrm{La} / \mathrm{Sc}$ and $\mathrm{Yb} / \mathrm{Sc}$ ratios that are otherwise a hallmark of evolved rocks. Figure $8 \mathrm{~A}$ clearly demonstrates that the REE geochemistry of the troctolites has not been determined by mixing between very primitive troctolites and diabase liquid, as one might be tempted to conclude from the position of the troctolites in the $\mathrm{La} / \mathrm{Yb}$ vs. Yb diagram (Fig. 4). Figure $8 \mathrm{~A}$ indicates that the REE geochemistry of the Hole $922 \mathrm{~A}$ and $922 \mathrm{~B}$ troctolites are related to mixing with evolved liquids. Figure $8 \mathrm{~B}$ shows in more detail that the troctolites define mixing trends between barren troctolites ("Troc" end-member) and an enriched member, whose composition is, however, not constrained by the data. Mixing with a highly evolved residual liquid offers a neat explanation of the peculiar REE patterns of the troctolitic rocks from Holes 922A and 922B. It is indeed strange that such plagioclase-rich cumulate rocks exhibit such small positive Eu anomalies. If one would attribute the smaller Eu anomalies to a low $\mathrm{Eu}^{2+} / \mathrm{Eu}^{3+}$ ratio of the parental magma, one would admit oxidation-reduction conditions that appear to be atypical of the deep oceanic crust. It is much more straightforward to accept that the original, pronounced, positive Eu anomaly of the troctolites has been greatly reduced by addition of REE-enriched residual liquids having a pronounced, negative Eu anomaly. Such an explanation is consistent with the position of the troctolitic rocks from Site 922 in Figure 6 . Moreover, the model solves other problems presented by the troctolites from Holes 922A and 922B. First, the mixing model also explains the higher REE abundances in the troctolites from Holes $922 \mathrm{~A}$ and $922 \mathrm{~B}$ compared to the troctolitic rocks from Holes $921 \mathrm{~B}$ and $923 \mathrm{~A}$. Second, it obviates the need to postulate the existence of a separate, REE-enriched, parental magma for the plutonic suite from Holes 922A and 922B. It is not fortuitous that the enriched troctolites are associated with strongly REE enriched oxide gabbros.
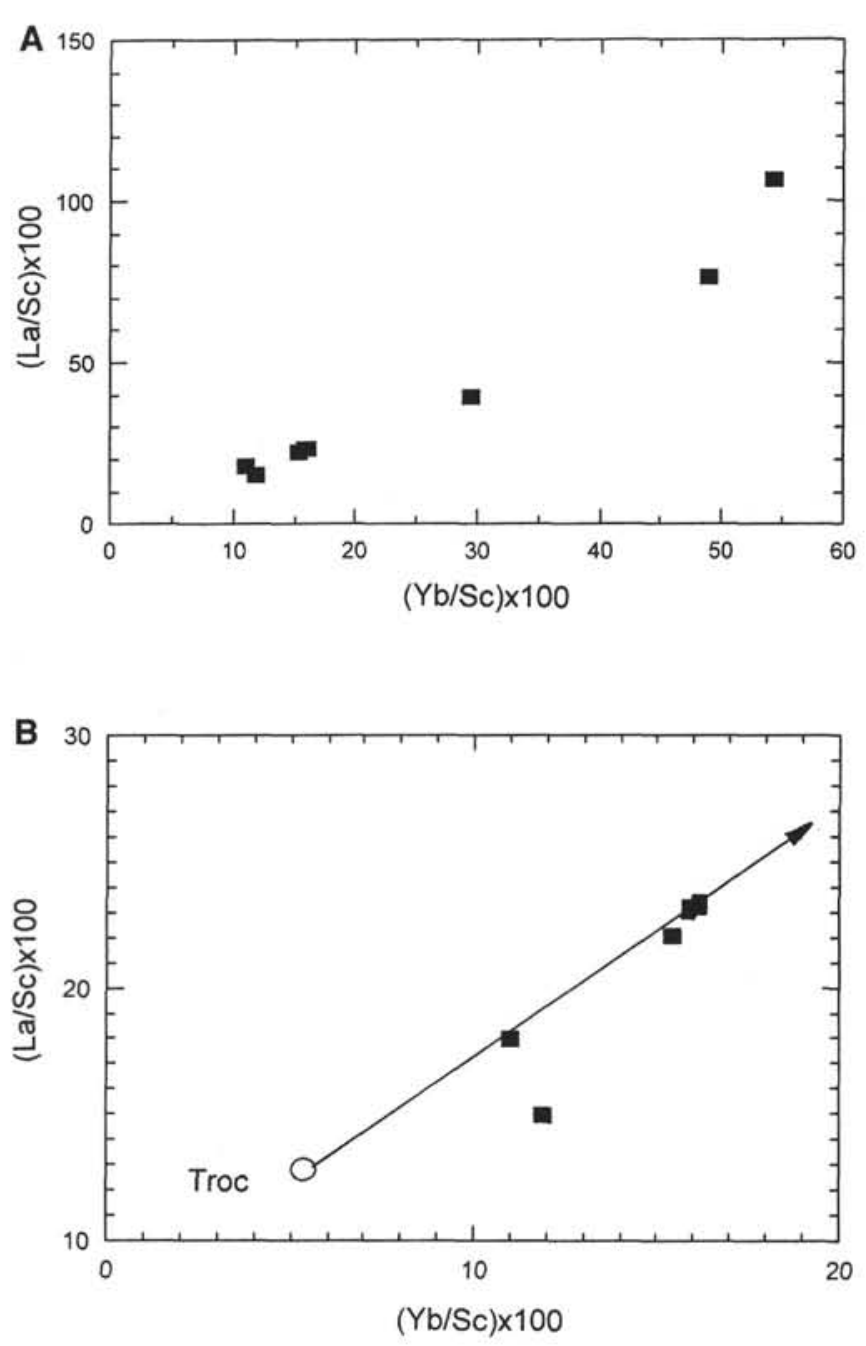

Figure 8. $\mathrm{La} / \mathrm{Sc}$ vs. $\mathrm{Yb} / \mathrm{Sc}$ mixing diagrams. A. Samples from Holes $922 \mathrm{~A}$ and $922 \mathrm{~B}$. Note the highly expanded scale compared to Figure 7. The samples fall outside the field defined by samples from the other holes. The samples in the lower left corner are troctolites. Oxide gabbros are situated in the right half of the diagram. B. Troctolitic samples from Holes 922A and 922B. The samples define a mixing trend between primitive, barren troctolites and a highly evolved end-member characterized by high $\mathrm{La} / \mathrm{Sc}$ and $\mathrm{Yb} / \mathrm{Sc}$ ratios.

In the case of gabbros from Hole 735B, it was observed that the formation of Fe-Ti oxide gabbros was generally accompanied by the formation of highly evolved, REE-rich, trondhjemitic residual liquids that play an important role in late-stage alteration processes (Hertogen, 1993; J. Hertogen, unpubl. data). All taken together, it appears that the peculiar geochemistry of the samples from Holes $922 \mathrm{~A}$ and 922B mainly reflects their formation in a ridge segment wherein conditions happened to be favorable for the protracted evolution of a small magma body.

In light of the explanation offered for the petrogenesis of Site 922 troctolitic rocks, one could ask why the same explanation is not acceptable for the troctolitic and gabbroic rocks from Sites 921 and 923. Indeed, the shift of most gabbros to the right of the model mixing curve in Figure 5 could, in principle, be attributed to mixing with rather small amounts of REE-enriched residual liquids having, for example, chondrite-normalized $\mathrm{Yb}$ contents in excess of 30 and $\mathrm{La} /$ $\mathrm{Yb}$ ratios close to 1 . But such an interpretation is inconsistent with the $\mathrm{Eu} / \mathrm{Sm}$ vs. Sm trend shown in Figure 6. If a fractionated end-member liquid component having a negative Eu anomaly had been involved in the genesis of the gabbros from Sites 921 and 923, most of the sam- 


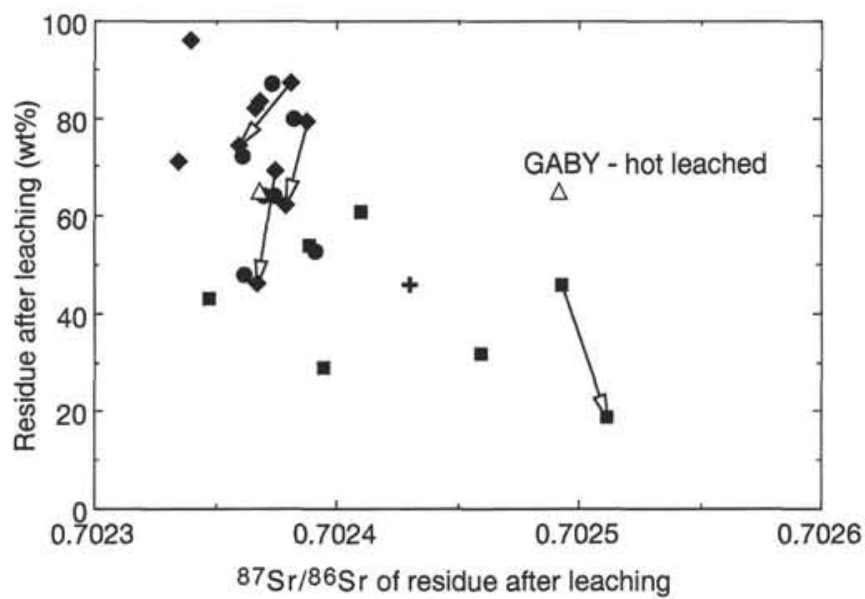

Figure 9. Residue after leaching (wt\%) vs. ${ }^{87} \mathrm{Sr} /{ }^{86} \mathrm{Sr}$ ratio. Arrows connect results for samples that were leached twice. Diamonds $=$ Site 921; squares $=$ Site 922; circles $=$ Site 923; cross $=$ diabase from Hole 921B ; open triangle $=$ GABY.

ple data should plot below, not above, the calculated mixing line. Furthermore, it appears from a simple comparison of the abundance of oxide gabbro and other evolved compositions in the recovered cores that evolved liquids were much less significant at Sites 921 and 923 than at Site 922 .

\section{Isotope Geochemistry}

Sites 921,922 , and 923 are all located at similar water depths (2450-2600 meters below sea level) and lie along a 2-km-long northsouth traverse along the western wall of the Mid-Atlantic Rift Valley roughly parallel to the median valley. Typically, isotopic variations in MORB are seen on the scale of tens, if not hundreds, of kilometers (e.g., Schilling, 1985). Therefore, given the close proximity of the three sites, it is reassuring and not surprising that the majority of MARK gabbros (sensu lato) have almost identical isotopic compositions and that they lie within the range of isotopic compositions for Atlantic MORB (Fig. 3).

The observed small variations are seen most markedly in the Srisotope ratios, which are believed to be the most easily disturbed during secondary processes. It is therefore interesting to note that, although leaching of individual samples results in a decrease of ${ }^{87} \mathrm{Sr} /$ ${ }^{86} \mathrm{Sr}$, the reverse is true for the data set as a whole, i.e., the smaller the residue remaining after leaching, the higher the ${ }^{87} \mathrm{Sr} /{ }^{86} \mathrm{Sr}$ value (Fig. 9). The same is not true for $\mathrm{Nd}$ - and $\mathrm{Pb}$-isotope ratios.

Two explanations for this observation spring to mind. First, the high ${ }^{87} \mathrm{Sr} /{ }^{86} \mathrm{Sr}$ values are primary $\mathrm{Sr}$-isotope compositions, which are coincidentally found in the most altered lithologies (i.e., gabbros from Site 922). Second, for more altered samples, even thorough leaching cannot completely remove secondary radiogenic $\mathrm{Sr}$. A third explanation, that leaching removes a nonradiogenic $\mathrm{Sr}$ component, is only supported by the leached pair for the most altered sample (Sample $153-922 \mathrm{~B}-3 \mathrm{R}-1,37-43 \mathrm{~cm}$ ) (Fig. 8). Although this is clearly not the case for fresher samples, it does suggest that, with extreme leaching of highly altered samples, $\mathrm{Sr}$ in primary phases is being lost preferentially over remaining secondary $\mathrm{Sr}$.

The REE and Sc systematics for Site 922 gabbros are interpreted as resulting from different petrogenetic processes from those involved in the formation of Site 921 and 923 gabbros. It is therefore tempting to suggest that the formation of these gabbros involved an isotopically distinct source. However, for both the oxide-rich gabbros and the troctolites and olivine gabbros, ${ }^{87} \mathrm{Sr} /{ }^{86} \mathrm{Sr}$ values range down to values within the field of Site 921 and 923 gabbros. Therefore, on balance, we believe that the variation in ${ }^{87} \mathrm{Sr} /{ }^{86} \mathrm{Sr}$ seen in Site 922 gab- bros probably results from incomplete leaching, and that their primary Sr-isotope ratios were within the range of values for Site 921 and 923 gabbros. However, the low ${ }^{207} \mathrm{~Pb} /{ }^{204} \mathrm{~Pb}$ and ${ }^{208} \mathrm{~Pb} /{ }^{204} \mathrm{~Pb}$ ratios of Site 922 gabbros at a given ${ }^{206} \mathrm{~Pb} /{ }^{204} \mathrm{~Pb}$ value are not consistent with incomplete removal of a radiogenic $\mathrm{Pb}$ component similar to that indicated by the leached/unleached pairs of Site 921 gabbros. Although this difference is scarcely larger than the stated error, it may be real, and if so, is the only evidence of isotopic heterogeneity in MARK gabbros. With the data we have it is not possible to say whether this isotopic heterogeneity was carried by the parental magmas to the original cumulates and/or the evolved liquids involved in the generation of Site 922 gabbros. If the latter is the case, then isotopic heterogeneity is not necessarily a feature of the mantle source of MARK gabbros.

The lack of any detectable isotopic difference between undeformed and deformed and recrystallized gabbros indicates that (1) significant quantities of seawater did not penetrate the oceanic lithosphere to depths where high-temperature deformation occurred, and (2) in cases where melt is believed to have been present during deformation, this melt was not isotopically distinct from the parental magmas of the cumulus minerals.

\section{CONCLUSIONS}

Trace-element variations in Site 921, 922, and 923 gabbros reflect the cumulate mineralogy of the samples, which vary in composition from troctolite to gabbro (sensu stricto) to oxide-rich gabbro. The parental magma for these cumulates was a rather homogeneous, moderately depleted, normal MORB with REE characteristics not dissimilar to those of diabases recovered at Site 921.

The first-order variations in REE and Sc abundances of gabbros from Sites 921 and 923 can be explained by a simple model in which it is assumed that the troctolitic rocks and gabbros (sensu stricto) consist of a fairly primitive cumulate fraction and variable amounts of trapped intercumulus liquid represented by the average parental liquid. This trapped intercumulus liquid has a profound effect on the trace-element composition of troctolitic rocks. The modeling also indicates that the REE geochemistry of the cumulate rocks was noticeably affected by open-system adcumulus growth and intercumulus liquid differentiation.

In contrast, Site 922 troctolites have remarkably high REE abundances and $\mathrm{La} / \mathrm{Sc}$ and $\mathrm{Yb} / \mathrm{Sc}$ ratios, characteristics normally associated with evolved compositions. The REE geochemistry of these troctolites is accounted for by mixing between barren troctolites and an enriched, perhaps trondhjemitic, residual liquid related to the formation of the $\mathrm{Fe}-\mathrm{Ti}$ oxide gabbros with which these troctolites are associated. The geochemistry of the Site 922 samples thus largely reflects more protracted magma evolution than that inferred from the geochemistry of Site 921 and 923 gabbros.

$\mathrm{Sr}-, \mathrm{Nd}-$, and $\mathrm{Pb}$-isotope ratios for undeformed and deformed and recrystallized gabbros from Sites 921 and 923 are almost identical, within error: ${ }^{87} \mathrm{Sr} /{ }^{86} \mathrm{Sr}=0.70234-0.70239 ;{ }^{143} \mathrm{Nd} /{ }^{144} \mathrm{Nd}=0.51324$ $0.51319 ;{ }^{206} \mathrm{~Pb} /{ }^{204} \mathrm{~Pb}=18.02-18.07 ;{ }^{207} \mathrm{~Pb} /{ }^{204} \mathrm{~Pb}=15.42-15.47$; and ${ }^{208} \mathrm{~Pb} /{ }^{204} \mathrm{~Pb}=37.37-37.54$. These values are typical of MORB, and lie toward the depleted extreme of values for Atlantic MORB. The only probable primary isotopic heterogeneity seen in the MARK gabbros is the slightly lower ${ }^{207} \mathrm{~Pb} / 204 \mathrm{~Pb}$ and ${ }^{208} \mathrm{~Pb} / 204 \mathrm{~Pb}$ ratios of Site 922 gabbros at a given ${ }^{206} \mathrm{~Pb} /{ }^{204} \mathrm{~Pb}$ value relative to Site 921 and 923 gabbros. On the basis of this study, we cannot say whether this isotopic heterogeneity was carried by the parental magmas to the original cumulates and/or the evolved liquids involved in the generation of Site 922 gabbros.

The Site 921 diabase has more radiogenic $\mathrm{Sr}-\left({ }^{87} \mathrm{Sr} /{ }^{86} \mathrm{Sr}=\right.$ 0.70243 ) and $\mathrm{Pb}$ - (e.g., ${ }^{206} \mathrm{~Pb} /{ }^{04} \mathrm{~Pb}=18.12$ ) isotope ratios than Site 921 and 923 gabbros, but its ${ }^{143} \mathrm{Nd} /{ }^{144} \mathrm{Nd}(0.513221)$ is within the range of values for gabbros. 


\section{ACKNOWLEDGMENTS}

The authors are grateful to G. Ceuleneer and M. Cannat for contributing three of the deformed samples, and to D. Coetermans for the major-element analyses. This work has been funded by grants from the Belgian National Science Foundations (FNRS grants to JB and DW, and NFWO grants to JH).

\section{REFERENCES}

Cannat, M., Karson, J.A., Miller, D.J., et al., 1995. Proc. ODP, Init. Repts. 153: College Station, TX (Ocean Drilling Program).

Detrick, R., Honnorez, J., Bryan, W.B., Juteau, T., et al., 1988. Proc. ODP, Init. Repts., 106/109: College Station, TX (Ocean Drilling Program).

Di Donato, G., Joron, J.L., Treuil, M., and Loubet, M., 1990. Geochemistry of zero-age N-MORB from Hole 648B, ODP Legs 106-109, M.A.R., $22^{\circ}$ N. In Detrick, R., Honnorez, J., Bryan, W.B., Juteau, T., et al., Proc. ODP, Sci. Results, 106/109: College Station, TX (Ocean Drilling Program), 57-65.

Drake, M.J., 1975. The oxidation state of europium as an indicator of oxygen fugacity. Geochim. Cosmochim. Acta, 39:55-64.

Hertogen, J., 1993. Trace element fractionation attending plutonic differentiation of Oceanic Layer 3: the case of ODP Hole 735B, S.W. Indian Ridge. Eos, 74 (Suppl.): 653.

Hertogen, J., and Gijbels, R., 1971. Instrumental neutron activation analysis of rocks with a low energy photon detector. Anal. Chim. Acta, 56:61-82.

Langmuir, C.H., 1989. Geochemical consequences of in situ crystallization. Nature, 340:199-205.

Langmuir, C.H., Vocke, R.D., Jr., Hanson, G.N., and Hart, S.R., 1978. A general mixing equation with applications to Icelandic basalts. Earth Planet. Sci. Lett., 37:380-392.

Lesher, C.E., and Walker, D., 1988. Cumulate maturation and melt migration in a temperature gradient. J. Geophys. Res., 93:10295-10311.
Lipin, B.R., and McKay, G.A. (Eds.), 1989. Geochemistry and Mineralogy of rare earth elements. Mineral. Soc. Am., Rev. Mineral., 21.

Mearns, E.W., 1988. A samarium-neodymium isotopic survey of modern river sediments from northern Britain. Chem. Geol. (Isotope Geosci. Sect.), 73:1-13.

Mearns, E.W., Knarud, R., Ræstad, N., Stanley, K.O., and Stockbridge, C.P., 1989. Samarium-neodymium isotope stratigraphy of the Lunde and Statfjord Formations of Snorre Oil Field, northern North Sea. J. Geol. Soc. London, 146:217-228.

Potts, P.J., 1987. A Handbook of Silicate Rock Analysis: Glasgow and London (Blackie).

Robinson, P.T., Von Herzen, R., et al., 1989. Proc. ODP, Init. Repts., 118: College Station, TX (Ocean Drilling Program).

Schilling, J.-G., 1985. Upper mantle heterogeneities and dynamics. Nature, 314:62-67.

Schnetzler, C.C., and Philpotts, J.A., 1970. Partition coefficients of rare-earth elements between igneous matrix material and rock-forming mineral phenocrysts-II. Geochim. Cosmochim. Acta, 34:331-340.

Sun, C.-O., Williams, R.J., and Sun, S.-S., 1974. Distribution coefficients of $\mathrm{Eu}$ and $\mathrm{Sr}$ for plagioclase-liquid and clinopyroxene-liquid equilibria in oceanic ridge basalt: an experimental study. Geochim. Cosmochim. Acta, $38: 1415-1433$.

Vance, D., and O'Nions, R.K., 1990. Isotopic chronometry of zoned garnets: growth kinetics and metamorphic histories. Earth Planet. Sci. Lett., 97:227-240.

Weis, D., and Deutsch, S., 1984. Nd and Pb isotope evidence from the Seychelles granites and their xenoliths: mantle origin with slight upper-crust interaction for alkaline anorogenic complexes. Isot. Geosci., 2:13-35.

\footnotetext{
Date of initial receipt: 4 August 1995

Date of acceptance: 29 December 1995

Ms 153SR-027
} 